\title{
Do Boys Benefit from Male Teachers in Elementary School? Evidence from Administrative Panel Data
}

\author{
Patrick A. Puhani \\ Leibniz Universität Hannover \\ CReAM, University College London; SEW, University of St. Gallen; \\ Global Labor Organization (GLO); IZA, Bonn
}

November 2017

\begin{abstract}
With girls having overtaken boys in many education indicators, the "feminization" of elementary school teaching is causing debates about disadvantages for male students. Using administrative panel data on the universe of students, teachers and schools for a German state, I exploit within school and within teacher variation to determine teacher characteristics' effects on students' tracking outcomes. Germany tracks students at age 10 into more or less academic school types. I find hardly any effects of teacher's gender, age, pay level, qualifications, or working hours on boys' or girls' school track recommendations or school choice. Even when following students into middle school, no effects of elementary-school teacher gender on school type change or grade repetition can be detected.
\end{abstract}

JEL classification: $\mathrm{I} 21, \mathrm{~J} 45, \mathrm{~J} 71, \mathrm{~J} 78$

Keywords: education, gender, identification, fixed effects, teacher quality

Patrick A. Puhani

Leibniz Universität Hannover

Institut für Arbeitsökonomik

Königsworther Platz 1

D-30167 Hannover

Germany

Phone: $\quad++49-511-762-5620$

E-Mail: puhani@aoek.uni-hannover.de

Acknowledgment: This research would not have been possible without the onsite data access provided by the Ministry of Culture and Education of the State of Hesse (Hessisches Kultusministerium) in cooperation with the Research Data Centre (Forschungsdatenzentrum) of the Statistical Office of the State of Hesse (Hessisches Statistisches Landesamt). I thank anonymous referees, Manuel Boos, Marc Deutschmann, Peter Gottfried, Bertrand Koebel, Stephen Machin, Dominique Meurs, Martin Pachl, Michele Pellizzari, Aderonke Osikominu, Nicole Purnhagen, Alexander Richter, Regina Riphahn, Jonah Rockoff, Claudia SchäfelSold, Thorsten Schank, Claus Schnabel, Elena Stancanelli, Stephan Thomsen, Rudolf Winter-Ebmer, Philip Yang, Martina Zweimüller, and seminar participants at the Associazione Italiana di Economisti del Lavoro (AIEL) in Trento, the Centre for European Economic Research (ZEW), Mannheim, the Economics of Education Group of the German Economic Association, the European Association of Labour Economists Conference at St. Gallen, the European University Institute, Florence, the German Economic Association (Verein für Socialpolitik) in Münster, the Institute for the Study of Labor (IZA), Bonn, the Institut National $\mathrm{d}^{`}$ Etudes Démographiques (INED), Paris, the Ministry of Culture and Education of the State of Hesse (Hessisches Kultusministerium), the Royal Economic Society Conference in Manchester, WifOR Wirtschaftsforschung, Darmstadt, and the Universities of Fribourg, Hohenheim, Linz, Lüneburg, Mainz, Nürnberg, Oldenburg, Paris Ouest Nanterre La Défense, Paris School of Economics, Strasbourg, and Tübingen for helpful comments. All errors are my own. 


\section{Introduction}

In recent decades, male students have been outperformed by female students in many subjects and countries (Machin and McNally, 2005; Machin and Pekkarinnen, 2008). At the same time, we have been observing a declining share of male teachers, which raises the question whether this gives male students a disadvantage. Such a disadvantage may arise due to either student or teacher behavior: students might learn less well if they lack a same-gender role model and teachers might lack understanding of behaviors by students of the opposite gender or simply prefer students of their own gender (for further discussions of these potential mechanisms see Hoffmann and Oreopoulos, 2009, Holmlund and Sund (2008), or Paredes, 2014). There have been debates in the international press about the "feminization" of the teaching profession, but the literature in education economics on the subject is rather small. In that literature, only Antecol, Eren, and Ozbeklik (2015) and Winters et al. (2013) study elementary schools. Eighth grade students are examined by Ehrenberg, Goldhaber, and Brewer (1995), Dee (2005, 2007), Cho (2012) and Paredes (2014). Nixon and Robinson (1999) and Holmlund and Sund (2008) examine high school students, whereas college/university students' outcomes by instructor gender are studied in Bettinger and Long (2005), Canes and Rosen (1995), Hoffmann and Oreopoulos (2009), Neumark and Gardecki (1998), Robst, Keil, and Russo (1998), and Rothstein (1995).

Much of this previous literature, especially the one on colleges/university, stresses the scarcity of female instructors, especially in some academic fields. However, it is male teachers who are scarce in elementary school, as various newspaper articles for Britain, Canada, France, 
Germany, Ireland, Korea, Switzerland, and the U.S. demonstrate. ${ }^{1}$ In these countries, the share of male teachers in elementary school is lowest among all school types, at between only 10 and 20 percent. Not only the scarcity of male teachers makes elementary schools important. If early treatments/interventions are more effective than programs attended later in life-as recent research in economics of human development suggests (Heckman, 2008)-elementary schools should matter more than subsequent school types.

In this paper, I use administrative data on the population of all students and teachers to estimate the effect of teacher gender and other teacher and classroom characteristics for male and female elementary school students in the German state of Hesse (which contains the city of Frankfurt). Because the data cover all students and all teachers of that state from 2007 through 2012, my estimates are based on almost 200,000 students or, in some specifications, 700,000 student by course observations. ${ }^{2}$

\footnotetext{
${ }^{1}$ Examples are: The Vancouver Sun (Canada), March 28, 2011: "Number of male teachers continues to decline"; Le Monde (France), October 19, 2009: "Face à la feminisation de la profession, Jean Ferrier propose de "revenir à des concours 'sexués'"' [Due to the feminisation of the profession, Jean Ferrier suggests to get back to contests by gender]; Die Zeit (Germany), August 5, 2010 "Was hilft den Jungen?" [What helps the boys?], die tageszeitung (Germany), October 5, 2011 "Männliche Lehrer sterben aus" [Male teachers are dying out], The Irish Times (Ireland-Eire) May 4, 2004 "Teaching in no-man's land"; The Korea Herald (South Korea), January 9, 2012: "Female teachers dominate middle, elementary schools", The Guardian (United Kingdom), July 31, 2007: "Missing male"; The Courier-Journal (United States), May 08, 2010: "Male teachers scarce in elementary classrooms".

${ }^{2}$ This is larger than the databases that were available for most previous studies, with the exception of Winters et al. (2013), who use administrative data on the state of Florida for 1.7 million students in different grades. Administrative data have also been used by Bettinger and Long (2005) who study the population of Ohio's 19981999 first-year students in public colleges, altogether about 54,000 observations; by Hoffmann and Oreopoulos (2009) who examine the 1996-2005 entry cohorts of the University of Toronto with altogether about 100,000 observations; by Holmlund and Sund (2008) who a analyze almost 43,000 student observations taken from Stockholm's upper secondary schools for the period 1997-2004; and by Robst, Keil, and Russo (1998) who obtained administrative files on about 6,000 students from the State University of New York at Binghamton. Other studies use survey or test data like the National Educational Longitudinal Study (NELS) of 1988, which yields up to 20,000 student by subject observations (Dee, 2007), the Trends in International Mathematics and Science Study (TIMSS) on 15 countries with a maximum of 15,000 observations per country used by Cho (2012), or Chile's System for Measuring the Quality of Education (SIMCE) on about 120,000 students. The randomized experiment by Antecol, Eren and Ozbeklik (2015) is based on slightly less than 2,000 observations.
} 
Elementary school, which usually lasts for four years (until age 10), is even more important in Germany than in most other countries, because Germany tracks students into physically segregated school types in middle school, which starts after grade 4 of elementary school. Hence, in the German case the potential stakes in elementary school are high. The tracking decision locks most students into an academically more or less challenging environment in terms of teaching curriculum and peers for a period of at least 5 years, that is the duration of middle school.

The German administrative school data do not contain test scores or school marks, but instead the most important outcome of German elementary school, namely the elementary school's middle school type recommendation and the actual middle school type attended in the following year. These decisions depend on the school marks unobserved in the administrative data.

Figure 1 illustrates the subjects (and corresponding hours) taught in fourth grade elementary school. The outcome variable in this study is whether a student attends or is recommended to attend the higher track middle school type. Education ministry regulations prescribe that the "learning development", "performance" and "work attitude", mostly in the main subjects Mathematics, German, and General Studies, form the basis for the middle school type recommendation given by the elementary school teachers. Parents, however, may ignore that recommendation when choosing the actual middle school type for their children. In the state of Hesse —as in 10 out 16 German states—parents thus have the final word on their children's educational choices.

The first outcome variable (i) teachers' middle school type recommendation is thus a measure of the student's general performance at the end of elementary school whereas the 
second outcome variable (ii) middle school type attended in the following year reflects parents' assessment of the optimal school choice of their children, which may be strongly influenced by the teachers' recommendation or not—depending on the strength of parents' priors. In the data set used here, recommendation and actual choice exhibit a more than $90 \%$ overlap. By estimating the effect of teacher gender on these two outcome variables, I capture (i) teacher gender's effects on overall student performance and (ii) teacher gender's effects on parents' decisions, which might be channeled through (i), but also contain parents' independent judgment on their child. These effects are determined separately for boys and girls.

The outcome variables in previous studies are (iii) test scores/grades (Ehrenberg, Goldhaber, and Brewer, 1995; Dee, 2007; Holmlund and Sund, 2008; Hoffmann and Oreopulos, 2009; Cho, 2012; Winters et al., 2013; Paredes, 2014; Antecol, Eren, and Ozbeklik, 2015), (iv) teacher performance expectations of their students (Paredes, 2014) or teacher perceptions of students like being disruptive, inattentive, or not doing homework (Ehrenberg, Goldhaber, and Brewer, 1995; Dee, 2005, 2007), or (v) students' perceptions of their courses like the perceived usefulness of the subject, or whether a student is looking forward to the course (Dee, 2007). Although outcome variables (iii) through (v) are not contained in the administrative teacher and student database for the German state of Hesse, we can regard the outcome variable (i) teachers' middle school type recommendation as a binary measure of a combination of indicators including (iii) test scores/grades and (iv) teacher's perceptions, and maybe to some extent also (v) students' attitudes. Apart from these outcomes, previous literature also considers retention (Robst, Keil, and Russo, 1998), further course choices (Bettinger and Long, 2005; Hoffmann and Oreopoulos, 2009) or further educational or career achievements as outcomes (Canes and Rosen, 1995; Neumark and Gardecki, 1998; Nixon and Robinson, 1999; Rothstein, 1995). In this study, 
I will also consider grade retention in elementary and in subsequent middle school (after the school type choice) as well as re-tracking during middle school (revision of initial school type choice in grades 6 or 7, Mühlenweg and Puhani, 2010) as additional outcome variables. Outcomes in middle school are particularly interesting, because they are not subject to potential teacher grading bias in elementary school.

Methodologically, we face the challenge of separating the causal effect of teacher gender on students' outcomes from confounding influences that may bias simple regressions. These confounding factors are not only (a) systematic differences in teacher characteristics such as experience or qualifications between male and female teachers, but also (b) sorting of male and female teachers into schools with students who differ systematically in their performances, for example due to different socio-economic backgrounds. For example, Black and Machin (2010) and Machin (2011) survey literature demonstrating that people are willing to pay more for houses belonging to districts with higher schooling quality. We therefore have to expect significant quality differences between schools even within small geographic areas like cities, due to residential sorting by socio-economic status. In addition to these problems, there may be (c) systematic sorting of male or female teachers within schools to more or less proficient students. For example, one might hypothesize that male teachers are allocated to more disruptive classes.

What we ideally want as researchers is a randomized design where teachers are randomly allocated a gender and randomly allocated to students/schools. In practice, however, we have to expect teacher gender to correlate with teacher quality, school quality, and socio-economic background of students, to the effect that simple OLS estimates of student outcomes on teacher gender may be biased. To address the three confounding factors mentioned in the previous 
paragraphs, the administrative data used in this study contain (a) information on teacher age, teacher pay level, teacher qualification, and teacher working hours to control for heterogeneity in these dimensions between male and female teachers. In addition, (b) systematic sorting of teachers of different gender into schools with different unobserved characteristics is controlled by estimating models that include school fixed effects on more than 1,100 elementary schools as well as models with school-by-year fixed effects.

Despite of all these controls available in the administrative data, we might still wonder whether male teachers are systematically allocated to classes with more challenging and less performing students within schools. Although the way classes are combined and teachers are allocated in German elementary schools makes this unlikely, I also estimate models following Dee (2007) with (c) teacher fixed effects. The panel nature of the administrative data makes it possible to control for teacher sorting based on unobserved classroom characteristics through these fixed effects. However, in this case, we can only identify the impact of "having a teacher of the same gender", and not the separate effects of having a male versus female teacher for boys and girls, respectively. The reason is that teacher gender does not vary "within teachers" (i.e. once teacher fixed effects are controlled for). However, there is still variation in the variable "having a teacher of the same gender" for each teacher, because teachers are teaching both male and female students (see also Dee, 2007).

Methodologically, only the more recent literature controls for school, student or teacher fixed effects to take into account systematic sorting of male and female teachers to different schools or classrooms. These are Winters et al. 's (2013) study on elementary, middle, and high schools, Dee's (2005, 2007), Cho's (2012), and Paredes's (2014) studies on eighth graders, Holmlund and Sund's (2008) analysis of upper secondary students, Bettinger and Long's (2005) 
and Hoffmann and Oreopoulos' (2009) study of college students, as well as Neumark and Gardecki's (1998) examination of U.S. graduate schools in Economics. The findings of these studies on whether instructor gender matters for students' outcomes are mixed: Winters et al. (2013) find no effects of teacher gender in Florida's elementary schools, but small positive effects of having a female teacher in middle and high schools for both genders. Dee $(2005,2007)$ reports significant benefits of having a teacher of the same gender for $8^{\text {th }}$ graders in the United States, Parades (2014) finds positive effects only for female students in Chile, but Cho's (2012) hardly detects any effects in fifteen OECD countries using TIMSS (Trends in International Mathematics and Science Study) data. Holmlund and Sund (2008) find no such effects for Swedish upper secondary schools, but point out that if one fails to control for teacher sorting into subjects, such effects, although spurious, might appear. Hoffmann and Oreopulos (2009) find very small effects (one to five percent of a standard deviation; where males perform worse if they have a female instructor) for the entry cohorts into the University of Toronto. For Economics Ph.D. programmes, Neumark and Gardecki (1998) cannot detect any effects of female faculty or female supervisors on first placements (except that more female faculty decrease women's duration in the Ph.D. program). Antecol, Eren and Ozbeklik (2015) is the only study relying on a randomized control trial. For elementary schools in disadvantaged neighborhoods, the authors find - contrary to the panel estimates by Winters et al. (2013) that female teachers reduce math (but not reading) test scores of female elementary school students, but have no effect on male students in either math or reading.

This paper is structured as follows. Section 2 explains the German tracking system and the administrative data used in this study. I use data from the German state of Hesse, which is the only German state that provides a comprehensive administrative data set where teacher and 
student characteristics can be linked for the complete population of schools, teachers and students. As a result, the data cover more than 1,100 elementary schools, more than 11,900 teachers, and almost 200,000 students in these schools over four school years. Section 3.1 explains the fixed-effects identification strategy and the variation in the data off which the estimates are obtained. Even after controlling for fixed effects, there is still significant variation in teacher gender that can be used to provide precise estimates of the teacher gender effect. The estimates of the effects of teacher gender on male and female school type recommendations and choices are presented in Section 3.2. Once school fixed effects are controlled for, almost no effects of teacher gender on either school recommendation or school choice can be detected: point estimates are close to zero and thanks to the large sample sizes, standard errors are small. This is true for both male and female students, so that male students do not benefit in terms of school type choice from being taught by a male teacher (they do benefit by slightly increasing their chances of being recommended a higher school type, but the effect is small). Alternative specifications reported in Section 3.3, where I include teacher fixed effects to identify the effects of "having a teacher of the same gender", also produce insignificant point estimates close to zero with small standard errors. There also seem to be no effects of teacher gender on deferring the school tracking decision, repeating the last grade of elementary school or subsequent grades in middle school, or on re-tracking after having made the first school type choice, as shown in Section 3.4 .

An investigation of the effects of other teacher, student and classroom characteristics on school type recommendation and choice is presented in Section 3.5. Again, no effects of teacher pay, qualification or working time are found for the outcome variables available in this study. 
Concurrent with previous literature, however, male students benefit from more female students in the classroom. Section 4 concludes.

\section{Institutional Facts and the Administrative Data Source}

\subsection{Tracking After Elementary School in Germany}

In almost all German states, elementary school lasts for 4 years, after which a student receives a recommendation for one of three middle school types. Traditionally, only the higher school type (called Gymnasium, similar to the traditional British grammar school), lasted for 9 years and led to a high school degree (similar to British A-levels) that qualified for college/university entry. The medium school type (called Realschule) takes 6 years and traditionally prepared for a white-collar apprenticeship, whereas the lower school type usually takes 5 years and traditionally prepared for a blue-collar apprenticeship. Several states have recently started to combine the medium and the lower school types. Because of this, because the lower school type does not receive many students in the state of Hesse any more, and because only the higher school type awards a certificate to enter university, the empirical part of this study only distinguishes between the higher school type and any other school type.

Table 1 presents the distribution of students over school types and grades (5 through 9) in the state of Hesse for the school year 2007/08, the first school year we use. In the more recent cohorts (grade 5) almost half the students are in the higher school type. The share is somewhat higher for girls (45\%) than for boys (43\%). The remaining students are in other institutions such as the medium school type, a comprehensive school, a so-called support stage, which allows to defer tracking until grade 7 (see also Mühlenweg, 2008), or a lower school type. 
The process for determining the choice of school type is regulated by state school laws and further decrees and is supposed to be based on students' performance in Mathematics, German, and General Studies (in German: Sachunterricht); see the illustration in Figure 1. The number of school hours (a school hour corresponds to 45 minutes) taught per week at the end of elementary school (fourth grade) in Hesse are 25 hours in total, of which 5 hours of Mathematics, 5 hours of German, 4 hours of General Studies, 4 hours of Arts and Music, 3 hours of Physical Education (Sports), 2 hours of Religious Education or Ethics and 2 hours of a Foreign Language (usually English). Mathematics, German, and General Studies are regarded as major subjects and hence form the basis for the school type recommendation, which is formally issued by the teachers' committee that is headed by the school principal and where each teacher has the same voting power. However, according to my telephone interviews with school principals, in practice, the committee usually follows the recommendation of the teachers in the three major subjects (or the main teacher who usually teaches in at least one of these subjects). The criteria for the recommendation are based on the student's "learning development, state of performance and work attitude" as well as the teachers' expectation on a successful attendance of the recommended middle school type by the student. ${ }^{3}$ Hence, it is not relative performance at elementary school that determines suitability, but more of an absolute standard, albeit not clear cut, that should be reached to be deemed fit for a certain school type. In Hesse, as in the majority of German states, parents can override the school type recommendation and send their children

\footnotetext{
${ }^{3}$ See $\S 9$ of the "Decree on the Design of the Schooling Environment" (own translation, German title: Verordnung zur Gestaltung des Schulverhältnisses, downloaded from:

zaa.schule.hessen.de/gesetz/2011_09_27_Schlussfassung_Amtsblatt_19-8-11.pdf on October 26th, 2017.
} 
to the type of school they find appropriate for their child (see the illustration in Figure 1). ${ }^{4}$

Receiving middle schools cannot refuse to accept a student except they reach capacity limits.

\subsection{Administrative Student-Teacher Data for the State of Hesse}

The present study draws on administrative linked teacher and student five-year panel data (in German: Lehrer- und Schülerdatenbank, LUSD) for the universe of teachers, students and schools in the German state of Hesse, which includes the major city of Frankfurt and which is the only German state that makes such linked teacher-student panel data available for research in Germany. The data are available for the school years 2007/2008 to 2011/12. ${ }^{5}$ For the same years, there is a course database which lists all the courses taught per school year (containing information such as the subject of the course). The administrative course database can be linked to the administrative student and teacher database.

The teacher database carries person level information on the gender, age, pay level, highest teaching qualification, citizenship, and working hours of the teacher. The student database carries information on the age, gender and citizenship of a student. It also carries a classroom identifier, which allows calculating the share of female and non-citizen peers. Unfortunately, there is no information on school marks/grades in the data. However, the data state the school type and thus the school track that a student attends. Thanks to the unique person identifier that is available since the school year 2007/2008, I can relate a student's teacher and

\footnotetext{
${ }^{4}$ As of 2008 , in 10 out of Germany's 16 states, the parents have the final word on the school type choice. In the other states, school marks or failure in special tests may prevent a child attending a higher school type.

${ }^{5}$ The state of Hesse has person-level student data since the school year 2002/03, but these data refer to students only, there are no linkable teacher data and the students cannot be followed over time due to lack of a panel identifier.
} 
classroom characteristics in grade 4 (the last grade of elementary school) to the school type chosen in grade 5 or later.

In addition to the actual track chosen in grade 5 , the data also contain the elementary school's track recommendation for about two-thirds of the students. This information is missing for the remaining third. I will address potential selection bias due to these missing observations by artificially restricting the sample for the school type choice estimates to those students for whom school type recommendation is also observed. It will turn out that the results are virtually unchanged by this sample restriction. Table 2 shows that school type recommendation and school type choice overlap for more than 90 percent of the observations in the data used in this study. Information on the sample size is given in Table A1. There are about 55,000 fourth graders in each calendar year who are observed in school in the state of Hesse in the following year. Only data for four out of five school years can be used, because data for the following year are required to observe the outcome variables school type attended or school type recommended.

There are two ways I structure the data, depending on the estimated model. In one set of estimates, I collapse the data on the student level such that there is exactly one observation for each student in each school year. Because each student follows several courses, the teacher gender variable in this data set will be the share of male teachers in the three main subjects German, Mathematics, and General Studies. In the models with teacher fixed effects, the data cannot be collapsed on the student level, because a student usually has more than one teacher. Therefore, the data are structured so that one observation is a student in a field course (say Mathematics). Hence, there are multiple observations per student in each year. The teacher gender variable in this data format is strictly binary. This latter data format is also required to 
compare students in courses with male or female teachers, as discussed in the following paragraph.

Table 3 reports sample means for the variables used in the analysis for a sample where each observation is a student in a field course. There are 628,740 observations in total. These observations refer to four school years for 198,155 students in 1,145 elementary schools. There are 11,900 different teacher observations teaching Mathematics, German, or General Studies in these schools.

Despite of some differences in the field course, age, pay level, qualification and working hours distributions between male and female teachers controlled for in the regression analyses, teachers of both genders teach similar students. As the lower part of Table 3 shows, the student gender, age, and student citizenship distributions are virtually identical among the observations referring to male and female teachers. Hence, any measured difference of students' outcomes between students taught by male and female teachers are unlikely to result from heterogeneity of the students taught by teachers of different gender, although I will also estimate models with teacher fixed effects to control potential sorting based on unobservable teacher or student characteristics. Fifty-one percent of the students obtain a higher school type recommendation and 44 percent of the students attend the higher school type in the following school year. 16 percent defer tracking for two years by entering the so-called Support Stage (Mühlenweg, 2008). Only about 1 percent of students repeat the fourth grade.

Splitting the sample by teacher gender reveals that only 10 percent (that is 1,193 out of $11,901)$ of the primary school teachers are male. Male teachers are somewhat more likely to teach Mathematics (38 percent) than female teachers (32 percent), but somewhat less likely to teach 
German (32 percent) than female teachers (37 percent). The share of General Studies is fairly equilibrated between the genders ( 30 and 31 percent for male and female teachers, respectively).

Teacher characteristics, especially the gender of the teacher, are central to this study. There is information on teachers' age (which is grouped into five dummy variables covering tenyear intervals 20-30, 30-40, etc.) and official working hours (coded into the three categories 020, 20-26, and 26-50). The administrative data also contain the teacher's salary group and qualification. As to the salary group, German teachers are usually civil servants, and hence paid according to a civil servant scale that ranges from A12 (common for primary school teachers) to A16 (common for a school principal of a higher school type). ${ }^{6}$ Especially early on in their career (or for health reasons), however, teachers may be public sector employees without civil servant status. In this case, another public sector pay scale applies. ${ }^{7}$ Although 75 percent of the observations are associated with teachers in civil service pay group A12, 7 percent are in public sector pay group BAT III and 9 percent are in civil service pay scale A13 (several of whom must be expected to be elementary school principals). 8 percent of the observations are paid according to other pay scales.

Teachers with the same pay level might still differ by qualification. There are different study curricula for teachers trained for different types of school. That is to say, students wanting to become a teacher already decide at the beginning of their college education whether they want to become an elementary school teacher or a teacher for secondary school of the lower, medium or high type. 77 percent of the observations in our population/sample have teachers with a regular elementary school teaching qualification. 9 percent have a higher qualification in that

\footnotetext{
${ }^{6}$ Teachers at the lower or medium school type would normally be classified as A13, teachers a the higher school type would usually be classified as A14. The pay scales A15 would usually apply to teachers with management functions, especially head master, in medium and higher school types.

${ }^{7}$ Traditionally, this was called BAT, but has been reformed and is now called TV-L.
} 
they would also be allowed to teach at a secondary school. 10 percent have a lower qualification (such as for special schools or kindergartens). The two remaining 4 percent have teachers with a different qualification, such as a specialization for a special subject (Fachlehrer) or a special permission to teach, or a missing in the variable.

\section{Empirical Analysis Using School and Teacher Fixed Effects}

\subsection{Identification Strategy and Empirical Results on the Variation in the Data Used to Identify the Effect of Teacher Gender}

The identification strategy employed in this paper is based both on (a) a rich set of teacher characteristics as control variables and on fixed effects, with (b1) school fixed effects, or (b2) school-by-year fixed effects, or (c1) teacher fixed effects or (c2) teacher-by-school fixed effects. The estimating equations take the following form:

$$
\begin{aligned}
y_{i \text { school } t}= & \alpha+\tau(\text { male teacher })_{i \text { school } t}+ \\
& \beta(\text { other teacher characterstics })_{i \text { school }}+ \\
& \gamma(\text { classroom characterstics })_{i \text { school } t}+ \\
& \delta(\text { student characterstics })_{i \text { school } t}+\phi_{t}+\mu_{\text {school }}+\varepsilon_{i \text { school } t}
\end{aligned}
$$

where the outcome variable $y$ is either the teacher's school type recommendation or the actual school type attended. $\phi_{t}$ are school year fixed effects; $\mu_{\text {school }}$ are school fixed effects. This set up thus corresponds to specification (b1). In specification (b2), I include school-by-year fixed effects, that is, there are separate fixed effects for each school in each school year. 
A priori it is unclear which type of fixed effects specification is preferable: if male teachers are assigned tougher classes, the within school variation in teacher gender in any school year will not be exogenous. This would bias both types of fixed effects estimates, but more so those with school-by-year (b2) than those with only school fixed effects (b1), because the former are uniquely based on the between classroom variation within a school in a given year. As it will turn out, there is no noteworthy difference between these two estimates, which, together with descriptive evidence on student characteristics by teacher gender and my telephone interviews, substantiates the view that within school variation in teacher gender is exogenous.

Nevertheless, to control any potential systematic assignment of male teachers to more challenging students, I also estimate models with teacher fixed effects (c). The specification with teacher fixed effects does not allow identification of a teacher gender effect, because teacher gender does not vary for a given teacher. However, this specification allows identification of the impact of having a teacher of the same gender and requires the assumption that this effect is similar for boys and girls. Because teachers teach both boys and girls the variable "teacher of same gender" varies for a given teacher in a student-by-course level data set. The specification is

$$
\begin{aligned}
y_{i \text { school } t}= & \alpha+\tau(\text { teacher of same gender })_{i}+ \\
& \gamma(\text { classroom characterstics })_{i \text { teacher }}+\delta(\text { student characterstics })_{i}+ \\
& \phi_{t}+\varpi_{\text {teacher }}+\varepsilon_{i \text { teacher }}
\end{aligned}
$$

where $\omega_{\text {teacher }}$ are teacher fixed effects (specification c1). In a variation of equation (2), I include teacher-by-school fixed effects (specification c2), which defines a new fixed effect if a teacher changes school. In all specifications (1) and (2), standard errors are clustered at the school level. 
The school fixed effects models (b1) and (b2) exhibited in equation (1) raise the question whether - after controlling for school fixed effects - there remains enough variation in the data. Here the question is whether there is sufficient variation in teacher gender within schools. Such variation may derive from two sources: teachers teaching the fourth grade in any school may vary over the school years or they may vary between classrooms within a school within a school year (in the state of Hesse, there are more than two classrooms on average in grade 4 during a school year).

The variation in the data that is used to identify the coefficients of equation (1) is presented in Table 4. To this end, I apply the Frisch-Waugh-Lovell theorem and regress each regressor on the fixed effects and all the other regressors of the estimating equation. According to the Frisch-Waugh-Lovell theorem, the standard deviation of the residual of these regressions exhibits the variation in the data used to identify the variable's coefficient in the fixed effects regression. ${ }^{8}$ The auxiliary regressions take the following form:

$$
\begin{aligned}
\text { (male teacher } & )_{i \text { school } t}+\pi_{1}+\pi_{2}(\text { other teacher characterstics })_{i \text { school } t} \\
& +\pi_{3}(\text { classroom characterstics })_{i \text { school } t} \\
& +\pi_{4}(\text { student characterstics })_{i \text { school } t}+\tilde{\phi}_{t}+\tilde{\mu}_{\text {school }}+\xi_{i \text { school } t}
\end{aligned}
$$

where the estimated standard deviation of the residual $\xi$ measures the variation in the data that is used to estimate the coefficient $\tau$ in equation (1). I estimated analogous equations for all other regressors in equation (1) and report the corresponding "within school" (i.e. residual of

\footnotetext{
${ }^{8}$ For binary variables, both mean and variance are driven by the same parameter.
} 
the auxiliary regression) variation in column 3 of Table 4 . The fourth column of Table 4 reports the "within school-by-year" variation in the variables, which are obtained from a variant of equation (3) that includes school-by-year instead of just year fixed effects.

Column 3 shows that even when controlling for school fixed effects with four school years of data, a substantial variation in teacher gender (as well as other teacher characteristics) still remains. After partialling out school fixed effects and all the other regressors, the standard deviation of "male teacher" only decreases from 0.25 to 0.22 . Hence, there remains enough variation in the data to exploit teacher gender variation in schools by way of school fixed effects regressions.

In column 4 of Table 4, instead of school fixed effects, I include school-by-year fixed effects. The variation of the residual of this regression exhibits the variation in teacher gender that is generated between classrooms within the same school and calendar year. As shown in column 4 of Table 4, this within school and within year variation in teacher gender is still substantial (0.17), albeit smaller than the total within school variation (0.22). Table 4 also demonstrates that the other teacher and student characteristics still exhibit significant variation even after controlling for school-by-year fixed effects.

\subsection{Teacher Gender's Effect on School Type Recommendation and School Type Choice using Variation in Teacher Gender within Schools}

Table 5 presents the coefficients of "male teacher" for different types of regression specifications. Because the data from the courses in Mathematics, German, and General Studies are collapsed at the student level, "male teacher" is the average exposure to a male teacher per student in all courses taken in fourth grade in the fields Mathematics, German and General Studies. Hence this variable can take on the values 0,1 , or values in between 0 and 1 ( 80 percent 
of classrooms have only female teachers, whereas 3 percent of classrooms have only male teachers in these three main subjects; the remaining 17 percent are taught by at least one male and one female teacher).

Different sets of control variables distinguish the four rows of estimates in Table 5. In the first row, no other control variables are included, the estimates thus corresponding to a raw mean comparison. In the second row, other teacher characteristics are included as controls, so that teacher gender is not confounded with differences in male and female teachers' age, pay level, teaching qualification, citizenship, and working hours.

The third and fourth rows present fixed effects estimates, with school fixed effects included in the third row and school-by-year fixed effects included in the fourth row. Apart from including the fixed effects just discussed, the third and fourth rows also include further control variables at the student (student gender, age, and citizenship) and enrollment or classroom level (enrollment size and the share of female and non-citizen students in the classroom), as well as a dummy variable for the school year. ${ }^{9}$ However, I have checked that adding these controls without the fixed effects does not make a decisive difference to the estimates. As it turns out, it is controlling for school fixed effects or not that impacts on the point estimate of having a male teacher.

Raw mean comparisons (the first row in Table 5) show that students with a male teacher on average have a 2.3 percentage point lower probability of being recommended to attend the higher school type and even a 4.3 percentage point lower probability of actually attending the higher school type one year after grade 4 elementary school. These negative and statistically significant effects hold for both male and female students, although having a male teacher is

\footnotetext{
${ }^{9}$ Enrollment size is more likely to be exogenous than class size, see Angrist and Lavy (1999). However, in my case results hardly change when controlling for class size (and its square) instead of enrollment size (and its square).
} 
associated with slightly more negative school type recommendations for female than for male students according to the point estimates (the difference between the estimates for boys and girls is not statistically significant).

However, the effects become smaller when other teacher characteristics (age, pay level, qualification, citizenship and working hours) are included as control variables (second row). They now reach 1.7 and 3.2 percentage points for school type recommendation and actual school type attended, respectively. Still, the point estimates of the association of having a male teacher is negative for female and positive for male students when school type recommendation is the outcome variable: the values are -1.9 and 1.2 percentage points, respectively.

However, once school fixed effects are included to account for unobserved confounding factors that may be correlated with the school indicator, the point estimates of having a male teacher become closer to zero (between -0.5 and 1.3 percentage points for all students for school type recommendation and school type choice, respectively) with only the latter estimate for school type recommendation statistically significant at the 10 percent level. All estimates for the separate male and female student populations and all estimates with school-by-year fixed effects are statistically insignificant for both school type recommendation and school type choice as the outcome variable. All point estimates are close to zero with small standard errors at only around 1 percentage point. The point estimates are similar when school-by-year instead of only school fixed effects are included: as the last two rows of the estimates show, the type of fixed effects makes hardly any difference to the point estimates (this finding is further discussed in Section $3.3)$.

Figure A1 in the Appendix displays power curves for a larger and a smaller standard error observed for the estimates in Table 5. Even for the larger standard error of 0.014 , the power of 
the $t$-test corresponding to an alternative hypothesis of 0.05 is above 90 percent. One may also wonder whether the binary outcomes school type recommendation or choice would react to potential effects on school marks or test scores, which unfortunately are not observed in the administrative data. A simple simulation demonstrates that with a sample of 200,000 students, an effect of teacher gender of about 0.5 standard deviations on a test score (here a latent variable) would show up as statistically significant even with a binary outcome variable as observed in the German administrative data: when observing the latent variable ("test score"), the estimated coefficient of 0.50 standard deviations is associated with a $t$-value of 67 (a standard error of 0.0075), when using the binary indicator ("school type") as outcome variable, the estimated effect on attending the higher track middle school is 19 percentage points with a $t$-value of 52 (a standard error of 0.0037). ${ }^{10}$ Hence, with the large sample at hand, a binary indicator is sufficient to significantly identify effects on the underlying latent outcome.

Because a third of the students have a missing observation in the variable "school type recommendation", Table 6 checks whether these missing observations are likely to bias my estimates. ${ }^{11}$ To this end, I artificially restrict the "school type choice" sample to the students who

${ }^{10}$ The following Stata commands demonstrate the relationship between the coefficient of a regression with the latent ("test score") and alternatively the binary ("school type") dependent variable on a dummy treatment variable ("teacher is male"). The setup corresponds to the situation of the data analyzed here: 200,000 observations, 10 percent being "treated" (here having a male teacher) and about 50 percent of students ending up in the higher track middle school:

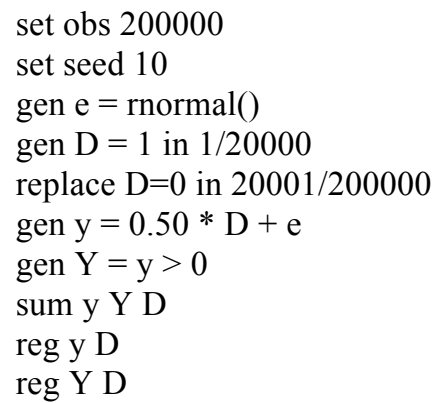

${ }^{11}$ Among the students with school type recommendation missing, 61 percent of the observations are not tracked, either because they decided to attend a comprehensive school (Gesamtschule, 31 percent among the observations with recommendation missing), deferred the tracking decision by two years by entering the support stage (Förderstufe, 26 percent among the observations with recommendation missing), or because they repeated the 
also have a valid entry for "school type recommendation". The adjacent columns in Table 6 then compare the estimates for "school type choice" for the restricted and the unrestricted sample. If the estimates turn out similar, the missing observations are unlikely to bias the estimates. As can be seen in Table 6, the estimates for the sample where the school type recommendation is not missing turn out to be similar to the estimates for the whole student population, although the restricted sample is by about one third smaller. It is particularly interesting that one important result holds in both samples: once I control for fixed effects, the small and sometimes significant effects found in the estimates without fixed effects disappear. Therefore, despite of missing values in the variable "school type recommendation", the sample for which we can observe this outcome variable seems to be informative.

Table 7 and Table 8 include further robustness checks. In Table 7, I limit the sample to students who are exclusively taught by male or exclusively taught by female teachers in the three main subjects (Mathematics, German, and General Studies), which is the case in 80 percent of the observations, because only about 10 percent of elementary school teachers are male. By focusing on students who are exposed only to one gender in the main subjects, we might expect that it was more likely to find an effect of teacher gender.

The fixed effects estimates in Table 7 provide some indication that having only male teachers in the three main subjects increases the probability to receive a recommendation of the higher school type. However, this effect shows for both boys and girls in the fixed effects

\footnotetext{
fourth grade of elementary school (4 percent among the observations with recommendation missing). The corresponding shares among observations with school recommendation not missing is only 12,11 , and 0 percent, respectively, adding up to 23 percent. Because all these choices are coded as 0 in the actual school choice variable, where only "higher school type" is coded as 1 , school type recommendation is not missing at random with respect to actual school type choice. However, the share of male elementary school teachers and male students (as well as other control variables) is almost identical in the subsamples with school type recommendation missing (10.6 percent male teachers, 51.4 percent male students) or not missing (10.0 percent male teachers and 50.4 percent male students). Hence school type recommendation seems to be missing at random with respect to having a male teacher or being a male student.
} 
regressions (not all estimates are statistically significant). The point estimates indicate an increased probability by between 1.4 and 3.6 percentage points for having only male teachers. These effects seem not very large, given that more than 50 percent of students receive a recommendation for a higher school type, but still worth mentioning. In spite of these small positive effects on the track recommendation of having only male teachers, there is no such effect on the actual school type chosen: the final choice is made by the parents and all fixed effects estimates for actual school type chosen are statistically insignificant with point estimates close to zero.

A further robustness check is provided in Table 8, where I include all subjects taught, not just the three main subjects Mathematics, German, and General Studies. The impact variable thus corresponds to the average exposure to male as opposed to female teachers in a wider set of courses and ranges from 0 to 1 . Table 8 reports the regression results according to the same structure as Table 5 and Table 7: estimates for the exposure to male teachers are reported for the outcome variables "school type recommendation" and "school type choice", both for all students together and for male and female students separately. In the specifications without fixed effects, point estimates are negative, with several of them statistically significant. When controlling for school or school-by-year fixed effects, however, these negative coefficients mostly disappear and most point estimates are close to zero and insignificant. An exception are the results for "school type recommendation" for boys, where the point estimates are statistically significant at 2.7 and 3.4 percentage points. The size of these effects is similar to the estimates in Table 7 , hence not very large.

Similar to the results found in Table 7, the positive effects found for boys for having a male teacher on their school type recommendation do not have a real impact, because the 
estimates for actual school type choice in Table 8 (just as in Table 7) are close to zero and statistically insignificant. Hence, it seems any positive effects of male elementary school teachers or any negative effects of female elementary school teachers on boys are neutralized by the parents' final word on their children's school type choice. This result may be seen as speaking in favor of involving parents in the school type choice.

So far, all analyses estimated the effects of teacher gender in fourth grade on school type recommendation and choice. In Table $\mathrm{A} 2$ in the Appendix, I report $F$-statistics and their $p$-values from regressions that include teacher gender both in fourth and third grade (first four columns) and teacher gender in fourth, third, and second grade (last four columns). The $F$-statistics refer to the test of joint insignificance of the teacher gender variables in all grades included in the respective regression. Toward the bottom of the table, the correlation between the teacher gender variables in grades two and four and in grades three and four are reported: the teacher gender variables in grades three and four have a correlation of about 0.78 , whereas the teacher gender variables in grades two and four have a correlation of around 0.61 . The results show that in the fixed effects specifications, the teacher gender variables are mostly jointly statistically insignificant. For the school type choice outcome, however, in two specifications the $F$-statistic is statistically significant at the 10 percent and in one case at the 5 percent level for male students (columns 2 and 6 of Table A2). However, starting with the specifications including teacher gender in grades 3 and 4 (column 2), it turns out that the coefficients for male teacher (not shown here) in grades three and four have opposite sign and net each other out: the coefficient on male teacher in third grade equals -0.031 in the school fixed effects and -0.044 in the school-by-year fixed effects model (standard errors 0.014 and 0.018 , respectively). The coefficient on male teacher in fourth grade equals 0.026 and 0.049 for these two types of fixed effects models 
(standard errors 0.015 and 0.019 ), respectively. Hence, the two coefficients add up to close to zero in both cases, namely -0.005 and 0.005 , respectively, although the $F$-statistic is statistically significant at the 10 and 5 percent level, respectively, ( $p$-values of 0.09 and 0.03 , respectively). The sum of the coefficients of male teacher in the school fixed effects specification with a significant $F$-statistic in the model with teacher gender in grades 2, 3, and 4 (column 6) equals 0.028 , with the single coefficients being -0.018 (coefficient of male teacher in grade 2 ), -0.037 (grade 3), and 0.027 (grade 4). None of the three single coefficients is statistically significant at the 10 percent level. Given the high correlations between teacher gender across grades 2, 3, and 4, it is hard to identify the effects of having a male teacher in these separate grades in a school fixed effects model.

\subsection{Controlling for Sorting of Teachers into Specific Classrooms: Teacher Fixed Effects}

As explained in the Introduction, identifying the effects of teacher gender on students' school outcomes is subject to several problems, in particular (a) differences between male and female teachers in such characteristics as age and qualifications, (b) differences in the unobserved characteristics of students in schools with higher or lower shares of male teachers, and (c) the systematic sorting of male teachers into different kinds of classrooms within schools. The estimates so far, however, have only taken into account the first two problems, addressed by (a) controlling for the teacher characteristics age, pay level, qualification, citizenship, and work time and by (b) including school or school-by-year fixed effects. In fact, the similarity of the regression results for school to those for school-by-year fixed effects could be interpreted to mean that in this case, problem (c) is not an issue. That is, whereas school fixed effects use teacher gender variation within schools both between classrooms and over time (as teachers 
rotate between grades), school-by-year fixed effects only exploit variation between classrooms. Hence, if there were any bias from systematic sorting of male teachers into different kinds of classrooms within schools, the estimates using school-by-year fixed effects should exhibit a larger bias than those using school fixed effects. As these two types of estimates are very similar in all results so far, it is doubtful that any such bias exists of quantitative importance.

Nevertheless, as outlined in Section 3.1, the study data allow estimation of models with either (c1) teacher or (c2) teacher-by-school fixed effects to directly address systematic sorting of male teachers into different classroom types within schools. This calculation is expressed in equation (2) of Section 3.1. As also discussed in that section, when teacher fixed effects are included in the regression, only the coefficient on the impact variable "teacher of same gender" is identified and such identification must rest on the assumption that this effect is identical for male and female students.

The estimation results are reported in Table 9, where, as in previous tables, the outcome variables are "school type recommendation" and "school type choice". The results for the two different specifications of teacher fixed effects—simple teacher fixed effects (specification c1) and teacher-by-school fixed effects (specification c2) - are reported in the first and second rows, respectively. The second specification accounts for the fact that teachers may switch schools and the match between the same teacher and a different school may imply a different teacher fixed effect. As Table 9 clearly shows, having a teacher of the same gender has no effect on either school type recommendation or school type choice: the point estimates are virtually zero and also 
statistically insignificant. This finding holds for both kinds of fixed effect specifications: teacher fixed effects and teacher-by-school fixed effects. ${ }^{12,13}$

\subsection{Teacher Gender Effects on Tracking Deferral, Grade Repetition and Track Change in Middle School}

Even though virtually no effects of teacher gender on school type recommendation and school type choice are detectable, there still remains the possibility that teacher gender might affect other outcomes such as "grade repetition" in the last year of elementary school or "tracking deferral" by two school years to attend a so-called support stage school (Mühlenweg, 2008). Table 10 reports the effects on these two outcomes of having a male teacher. None of the fixed effects models exhibit any statistically significant coefficients, and all the point estimates in these models are very close to zero.

Nevertheless, in theory, it is possible that male and female teachers do have different effects on the study progress of male and female students but that these effects are neutralized by teachers' grading habits and subsequent school type recommendation (Ouazad and Page, 2013). Hence, to obtain a more objective outcome that is outside the elementary teachers' control, Table 11 reports outcomes determined in middle school and thus by different teachers. Because of their panel nature, the data allow follow-up of students over time to identify the grade (e.g., 6th or 7th) three years after the school type choice, which amounts to a cumulative measure of grade repetition. They also allow generation of an indicator for school type change (re-tracking) two

\footnotetext{
${ }^{12}$ In Table 9, because students may have different teachers in different subjects, the data are collapsed on the course and not the student level, which explains the larger number of observations.

${ }^{13}$ It should be kept in mind, however, that the identification of the "teacher of opposite gender" effect is only possible in the teacher fixed effects models under the assumption that this effect is identical for male and female students. The previous estimates based on school and school-by-year fixed effects suggest that such is not the case, at least not when "school type recommendation" is the outcome variable.
} 
years after the initial tracking decision, denoted by -1 for a downgrade, 0 for no change, and 1 for an upgrade. Because the data set includes 5 school years of observations, however, looking ahead from grade 4 to (assumedly) grade 7 reduces the number of analyzable cohorts to just two and shrinks the population/sample size accordingly. Nevertheless, the standard errors of the estimates using these outcome variables are not very large (a little more than half a percentage point) and no estimates are statistically significant (see Table 11). Therefore, teacher gender has virtually no effect on the student outcomes considered in this study.

\subsection{Other Teacher and Classroom Characteristics' Effects on School Type Recommendation and School Type Choice}

Even though the effects of teacher gender on school type recommendation or school type choice seem minimal, it is worth investigating whether these outcomes can be explained by any of the other control variables not yet discussed. Table 12 and Table 13 display the full regression results for the school fixed effect regressions reported in Table 5. The $\mathrm{R}^{2}$ at the bottom of the tables indicate that the regressors explain about 20 percent of the variation in the (binary) outcome school type recommendation and about 16 percent of the (binary) outcome school type choice. About half of the explained variation is due to school fixed effects and the other half to the regressors, whose coefficients are given in the tables. One particularly interesting result is that virtually none of the other teacher characteristics - neither teacher age, pay level, qualifications, citizenship, nor work hours-has any effect on school type recommendation or school type choice. The few teacher characteristics that are significant usually have very small point estimates, around 2 or 3 percentage points, so no systematic pattern is derivable.

The explanatory power of these models, however, derives not only from the school fixed effects but also from the individual student and the enrollment/classroom characteristics. In both 
Table 12 and Table 13, student gender, age, and citizenship are highly significant, with large point estimates for age and student citizenship. As to age, older students are less likely to be recommended to the higher school type or to choose that school type because it is the less proficient students who usually enter school later (Mühlenweg and Puhani, 2010). Likewise, students with foreign citizenship, whether male or female, are significantly less likely to attend or be recommended to the higher school type. Nevertheless, the estimates for student age and citizenship are also driven by variation between individual students within classrooms and thus not derived from quasi-experimental variation in these characteristics and unlikely to carry a causal interpretation.

Another interesting finding, one that echoes Lavy and Schlosser (2011), is that a higher share of female students in the classroom benefits male students. This finding holds true regardless of whether the outcome variable is school type recommendation (Table 12) or school type choice (Table 13). The effect, however, is not very large: the share would need to rise from 0 to (almost) 100 percent in order to generate a 6 percentage point increase in the probability that a male student be recommended to or attend the higher school type. No such effect is found for female students. It is also noteworthy that the share of non-European students in the classroom is not significant in these regressions, with point estimates close to zero.

\section{Conclusions}

The scarcity of male teachers in elementary school is leading to debate on whether young boys require more male role models in school and whether boys might be discriminated against by female teachers. This present analysis takes advantage of administrative data on the 
population of students and teachers in the German state of Hesse to estimate teacher gender effects on elementary school outcomes.

The evaluation of within school variation, however, which controls for school fixed effects, identifies virtually no effects of teacher gender at the end of elementary school (grade 4, age 10) on either the teachers' recommendations for middle school type choice or the actual school type choice (in Germany's early tracking system). The one exception is that boys might benefit slightly in terms of a higher school type recommendation when taught by a male teacher, although there is no such effect on actual school type choice, probably because parents have the final word on this latter. Nor do the teacher fixed effects models reveal any effects of being taught by a teacher of the same gender on either outcome variable. The findings in this paper, therefore, should allay the concerns expressed in the global press that the increasing feminization of elementary school education might harm boys.

\section{References}

Angrist, J.D. and V. Lavy, 1999. Using Maimonides' Rule to Estimate the Effect of Class Size on Scholastic Achievement, Quarterly Journal of Economics 114, 533-575.

Antecol, H., Eren, O. and S. Ozbeklik, 2015. The Effect of Teacher Gender on Student Achievement in Primary School, Journal of Labor Economics 33, 63-89.

Bettinger, E.P. and B.T. Long, 2005. Do Faculty Serve as Role Models? The Impact of Instructor Gender on Female Students, American Economic Review Papers and Proceedings 95, 152-157.

Black, S.E. and S. Machin, 2011. Housing Valuations of School Performance, in: Hanushek, E.A., S. Machin, and L. Wößmann (eds.): Handbook of the Economics of Education, Vol. 3, San Diego, CA and Amsterdam: North-Holland, 485-519. 
Canes, B.J., H.S. Rosen, 1995. Following in Her Footsteps? Faculty Gender Composition and Women's Choices of College Majors, Industrial and Labor Relations Review 48, 486504.

Cho, I., 2012. The Effect of Teacher-Student Gender Matching: Evidence from OECD Countries, Economics of Education Review 31, 54-67.

Dee, Th. S., 2005. A Teacher Like Me: Does Race, Ethnicity, or Gender Matter?, American Economic Review Papers and Proceedings 95, 158-165.

Dee, Th. S., 2007. Teachers and the Gender Gaps in Student Achievement, Journal of Human Resources 42, 528-554.

Ehrenberg, R.D., D.D. Goldhaber and D.J. Brewer, 1995. Do Teachers' Race, Gender, and Ethnicity Matter? Evidence from the National Educational Longitudinal Study of 1988, Industrial and Labor Relations Review 48, 547-561.

Heckman, J.J., 2008. Schools, Skills, and Synapses, Economic Inquiry 46, 289-324.

Hoffmann, F. and Ph. Oreopoulos, 2009. A Professor Like Me, The Influence of Instructor Gender on College Achievement, Journal of Human Resources 44, 479-494.

Holmlund, H. and K. Sund, 2008. Is the Gender Gap in School Performance Affected By the Sex of the Teacher?, Labour Economics 15, 37-53.

Lavy, V. and A. Schlosser, 2011. Mechanisms and Impacts of Gender Peer Effects at School, American Economic Journal: Applied Economics 3, 1-33.

Machin, S. and S. McNally, 2005. Gender and Student Achievement in English Schools, Oxford Review of Economic Policy 21, 357-372.

Machin, S. and T. Pekkarinen, 2008. Global Sex Differences in Test Score Variability, Science $322,1331-1332$.

Machin, S., 2011. Houses and Schools: Valuation of School Quality Through the Housing Market, Labour Economics 18, 723-729.

Mühlenweg, A.M., 2008. Educational Effects of Alternative Secondary School Tracking Regimes in Germany, Schmollers Jahrbuch - Journal of Applied Social Science Studies $128,351-279$.

Mühlenweg, A.M. and P.A. Puhani, 2010. The Evolution of the School Entry Age Effect in a School Tracking System, Journal of Human Resources 45, 407-438.

Neumark, D. and R. Gardecki, 1998. Women Helping Women? Role Model and Mentoring Effects on Female Ph.D. Students in Economics, Journal of Human Resources 33, 220246. 
Nixon, L.A. and M.D. Robinson, 1999. The Educational Attainment of Young Women: Role Model Effects of Female High School Faculty, Demography 36, 185-194.

Ouazad, A. and L. Page, 2013. Students' Perceptions of Teacher Biases: Experimental Economics in Schools, Journal of Public Economics 105, 116-130.

Paredes, V., 2014. A Teacher Like Me or a Student Like Me? Role Model Versus Teacher Bias Effect, Economics of Education Review 39, 38-49.

Robst, J., J. Keil, D. Russo, 1998. The Effect of Gender Composition of Faculty on Student Retention, Economics of Education Review 17, 429-439.

Rothstein, D., 1995. Do Female Faculty Influence Female Students' Educational and Labor Market Attainment? Industrial and Labor Relations Review 48, 515-530.

Winters, M.A., R.C. Haight, Th.T. Swaim, K.A. Pickering 2013. The Effect of Same-Gender Teacher Assignment on Student Achievement in the Elementary and Secondary Grade: Evidence from Panel Data, Economics of Education Review 17, 429-439. 


\section{Tables and Figures}

Table 1: School Type Attendance Middle School in Percent (Grades 5 Through 9)

\begin{tabular}{lccccc}
\hline Grade/School Type & $\mathbf{5}$ & $\mathbf{6}$ & $\mathbf{7}$ & $\mathbf{8}$ & $\mathbf{9}$ \\
\hline Boys & & & & & \\
Non Higher School Types of which: & $\mathbf{5 7}$ & $\mathbf{6 0}$ & $\mathbf{6 1}$ & $\mathbf{6 2}$ & $\mathbf{6 5}$ \\
$\quad$ Lower School Type & 4 & 6 & 15 & 18 & 19 \\
Support Stage & 18 & 20 & 0 & 0 & 0 \\
Comprehensive School & 18 & 18 & 17 & 16 & 16 \\
Medium School Type & 17 & 16 & 28 & 29 & 30 \\
Higher School Type & $\mathbf{4 3}$ & $\mathbf{4 0}$ & $\mathbf{3 9}$ & $\mathbf{3 8}$ & $\mathbf{3 5}$ \\
Number of Students & 30,372 & 29,518 & 29,236 & 30,634 & 30,642
\end{tabular}

Girls

\begin{tabular}{lccccc} 
Non Higher School Types of which: & $\mathbf{5 5}$ & $\mathbf{5 6}$ & $\mathbf{5 6}$ & $\mathbf{5 7}$ & $\mathbf{6 1}$ \\
Lower School Type & 3 & 4 & 12 & 14 & 15 \\
Support Stage & 17 & 18 & 0 & 0 & 0 \\
Comprehensive School & 18 & 17 & 16 & 15 & 16 \\
Medium School Type & 17 & 16 & 28 & 28 & 30 \\
Higher School Type & $\mathbf{4 5}$ & $\mathbf{4 4}$ & $\mathbf{4 4}$ & $\mathbf{4 3}$ & $\mathbf{3 9}$ \\
Number of Students & 28,892 & 27,741 & 27,704 & 29,025 & 29,928 \\
\hline
\end{tabular}

Source: Administrative Teacher and Student Data Set for the State of Hesse 2007/08-2011/12 (Lehrer- und Schülerdatenbank, LUSD); own calculations.

Table 2: Overlap Between School Type Recommendation and School Type Choice

\begin{tabular}{lcc}
\hline & \multicolumn{2}{c}{ School Type Choice } \\
School Type & & \\
Recommendation & Not Higher & Higher \\
\hline Not Higher & 42.7 & 5.3 \\
Higher & 3.4 & 48.5 \\
\hline
\end{tabular}

Note: The figures represent percentages.

Source: Administrative Teacher and Student Data Set for the State of Hesse 2007/08-2011/12 (Lehrer- und Schülerdatenbank, LUSD); own calculations. 
Table 3: Sample Means by Teacher Gender

Total Sample Teacher is Male Teacher is Female

Outcome Variables

Teachers' Recommendation

0.51

0.44

0.50

0.52

Higher School Type Attendance

0.01

0.42

0.45

Grade 4 Elementary School Repetition

0.16

0.02

0.01

Tracking Deferral (Support Stage Attendance)

0.18

0.16

Teacher Characteristics

Teacher is Male

0.10

1.00

0.00

Teacher Age Group

20-30

0.10

0.05

0.12

$30-40$

0.26

40-50

0.22

0.24

0.25

50-60

0.34

0.25

0.22

60-70

0.08

0.36

0.34

Teacher Pay Level

Public Employee (BAT III)

0.07

0.10

0.08

Civil Servant (A12)

0.75

0.09

0.03

0.05

Civil Servant (A13)

0.08

0.66

0.77

Other

0.19

0.08

Teacher Qualification Level

Below Elementary

0.10

0.12

0.09

Elementary

0.77

0.13

0.11

Above Elementary

0.09

0.72

0.79

Other

0.04

0.09

0.07

0.06

0.03

Teacher Working Hours

$0-20$

0.14

0.03

0.15

$20-26$

0.22

0.07

0.24

26-50

0.64

0.90

0.61

Teacher Not a German Citizen

0.004

0.005

0.004

Course Characteristics (not used in the main regressions)

Subject Taught

German

0.37

0.32

0.37

Mathematics

0.32

0.38

0.32

General Studies

0.31

0.30

0.31

Enrollment/Classroom Characteristics

Share Female

0.51

0.51

0.51

Share Non-European

0.08

0.08

0.07

Enrollment Size

58.5

57.9

58.3

Class Size (not used in the regressions)

20.2

20.0

20.2

Student Characteristics

Student is Male

0.51

0.51

0.51

Student's Age

9.86

9.88

9.86 


\begin{tabular}{lccc} 
Student Citizenship & & & \\
German & 0.87 & 0.88 & 0.88 \\
Turkish & 0.05 & 0.05 & 0.04 \\
European, North American, Aus./NZ & 0.05 & 0.05 & 0.05 \\
Other & 0.03 & 0.03 & 0.03 \\
\# Schools Years & 4 & 4 & 4 \\
\# Schools & 1,145 & 717 & 1,142 \\
\# Classrooms & 10,247 & 2,100 & 9,900 \\
\# Teachers & 11,901 & 1,193 & 10,708 \\
\# Courses & 34,276 & 3,926 & 31,088 \\
\# Students & 198,155 & 37,904 & 190,733 \\
\# Observations & 694,429 & 72,512 & 621,917 \\
\# Obs. with Valid Teachers' Recommendation & 449,867 & 46,107 & 403,760 \\
\hline
\end{tabular}

Source: Administrative Teacher and Student Data Set for the State of Hesse 2007/08-2011/12 (Lehrer- und Schülerdatenbank, LUSD); own calculations. 
Table 4: Within Variation in the Data for Different Types of Fixed Effects

\begin{tabular}{|c|c|c|c|c|}
\hline & Mean & Std. Dev. & $\begin{array}{l}\text { Within School } \\
\text { Std. Dev. }\end{array}$ & $\begin{array}{c}\text { Within School } \\
\text { By Year Std. } \\
\text { Dev. }\end{array}$ \\
\hline \multicolumn{5}{|l|}{ Outcome Variables } \\
\hline Teachers' Recommendation & 0.52 & 0.50 & 0.45 & 0.44 \\
\hline Higher School Type Attendance & 0.45 & 0.50 & 0.46 & 0.45 \\
\hline Tracking Deferral (Support Stage Attendance) & 0.16 & 0.37 & 0.30 & 0.29 \\
\hline Grade Repetition (Elementary School Attendance) & 0.01 & 0.12 & 0.11 & 0.11 \\
\hline \multicolumn{5}{|l|}{ Teacher Characteristics } \\
\hline Teacher is Male & 0.10 & 0.24 & 0.21 & 0.17 \\
\hline \multicolumn{5}{|l|}{ Teacher Age Group } \\
\hline $20-30$ & 0.10 & 0.24 & 0.17 & 0.14 \\
\hline $30-40$ & 0.25 & 0.36 & 0.26 & 0.21 \\
\hline $40-50$ & 0.22 & 0.35 & 0.26 & 0.21 \\
\hline $50-60$ & 0.35 & 0.40 & 0.28 & 0.22 \\
\hline $60-70$ & 0.08 & 0.23 & 0.17 & 0.14 \\
\hline \multicolumn{5}{|l|}{ Teacher Pay Level } \\
\hline Public Employee (BAT III) & 0.07 & 0.21 & 0.18 & 0.14 \\
\hline Civil Servant (A12) & 0.77 & 0.33 & 0.18 & 0.14 \\
\hline Civil Servant (A13) & 0.09 & 0.21 & 0.18 & 0.14 \\
\hline Other & 0.07 & 0.19 & 0.15 & 0.12 \\
\hline \multicolumn{5}{|l|}{ Teacher Qualification Level } \\
\hline Below Elementary & 0.09 & 0.20 & 0.16 & 0.13 \\
\hline Elementary & 0.78 & 0.33 & 0.20 & 0.16 \\
\hline Above Elementary & 0.10 & 0.25 & 0.20 & 0.16 \\
\hline Other & 0.03 & 0.14 & 0.12 & 0.10 \\
\hline \multicolumn{5}{|l|}{ Teacher Working Hours } \\
\hline $0-20$ & 0.14 & 0.29 & 0.23 & 0.18 \\
\hline $20-26$ & 0.22 & 0.36 & 0.31 & 0.24 \\
\hline $26-50$ & 0.64 & 0.40 & 0.31 & 0.24 \\
\hline Teacher Not a German Citizen & 0.004 & 0.05 & 0.04 & 0.04 \\
\hline \multicolumn{5}{|l|}{ Enrollment/Classroom Characteristics } \\
\hline Share Female & 0.51 & 0.11 & 0.10 & 0.07 \\
\hline Share Non-European & 0.08 & 0.11 & 0.06 & 0.05 \\
\hline Enrollment/10 in Grade 4 & 5.9 & 2.6 & 0.25 & 0.00 \\
\hline \multicolumn{5}{|l|}{ Student Characteristics } \\
\hline Student is Male & 0.51 & 0.50 & 0.49 & 0.49 \\
\hline Student's Age & 9.85 & 0.50 & 0.48 & 0.47 \\
\hline \multicolumn{5}{|l|}{ Student Citizenship } \\
\hline German & 0.87 & 0.33 & 0.20 & 0.20 \\
\hline Turkish & 0.05 & 0.22 & 0.20 & 0.20 \\
\hline European, North American, Aus./NZ & 0.05 & 0.21 & 0.21 & 0.20 \\
\hline Other & 0.03 & 0.16 & 0.16 & 0.15 \\
\hline
\end{tabular}

Note: Because the data are collapsed at the student level, the teacher dummy variables are not binary any more in this format, because a typical student has more than one teacher in the three main subjects Mathematics, German, and General Studies. Sample/population size: 198,155 .

Source: Administrative Teacher and Student Data Set for the State of Hesse 2007/08-2011/12 (Lehrer- und Schülerdatenbank, LUSD); own calculations. 
Table 5: Regression Results: Coefficient of Male Teacher

\begin{tabular}{|c|c|c|c|c|c|c|}
\hline & \multicolumn{2}{|c|}{ All Students } & \multicolumn{2}{|c|}{ Male Students } & \multicolumn{2}{|c|}{ Female Students } \\
\hline & $\begin{array}{c}\text { School Type } \\
\text { Recommendation }\end{array}$ & $\begin{array}{c}\text { School } \\
\text { Type } \\
\text { Choice }\end{array}$ & $\begin{array}{c}\text { School Type } \\
\text { Recommendation }\end{array}$ & $\begin{array}{c}\text { School } \\
\text { Type } \\
\text { Choice }\end{array}$ & $\begin{array}{c}\text { School Type } \\
\text { Recommendation }\end{array}$ & $\begin{array}{l}\text { School } \\
\text { Type } \\
\text { Choice } \\
\end{array}$ \\
\hline No Controls & $-0.023 *$ & $-0.043 * *$ & -0.020 & $-0.044 * * *$ & $-0.024^{*}$ & $-0.041 * * *$ \\
\hline (s.e.) & $(.012)$ & $(.009)$ & $(.013)$ & $(.010)$ & $(.014)$ & $(.011)$ \\
\hline \# obs & 129,326 & 198,155 & 65,183 & 100,550 & 64,143 & 97,605 \\
\hline $\begin{array}{l}\text { Other Teacher Vars. } \\
\text { (s.e.) }\end{array}$ & $\begin{array}{l}-0.017 \\
(.012)\end{array}$ & $\begin{array}{c}-0.032^{* * * *} \\
(.009)\end{array}$ & $\begin{array}{l}0.012 \\
(.01)\end{array}$ & $\begin{array}{c}-0.031 * * * \\
(.01)\end{array}$ & $\begin{array}{l}-0.019 \\
(.014)\end{array}$ & $\begin{array}{c}-0.031 * * * \\
(.011)\end{array}$ \\
\hline \# obs & 129,326 & 198,155 & 65,183 & 100,550 & 64,143 & 97,605 \\
\hline School Fixed Effects & $0.013^{*}$ & -0.005 & 0.014 & 0.000 & 0.012 & -0.010 \\
\hline (s.e.) & $(.008)$ & $(.005)$ & $(.01)$ & $(.007)$ & $(.011)$ & $(.008)$ \\
\hline \# obs & 129,326 & 198,155 & 65,183 & 100,550 & 64,143 & 97,605 \\
\hline $\begin{array}{l}\text { School-By-Year FE } \\
\text { (s.e.) }\end{array}$ & $\begin{array}{l}0.014 \\
(.009)\end{array}$ & $\begin{array}{l}-0.002 \\
(.007)\end{array}$ & $\begin{array}{l}0.012 \\
(.011)\end{array}$ & $\begin{array}{l}0.007 \\
(.009)\end{array}$ & $\begin{array}{l}0.016 \\
(.013)\end{array}$ & $\begin{array}{c}-0.010 \\
(.01)\end{array}$ \\
\hline \# obs & 129,326 & 198,155 & 65,183 & 100,550 & 64,143 & 97,605 \\
\hline \# School Years & 4 & 4 & 4 & 4 & 4 & 4 \\
\hline \# Schools & 1,105 & 1,145 & 1,088 & 1,145 & 1,086 & 1,145 \\
\hline \# Classrooms & 8,187 & 10,247 & 8,005 & 10,230 & 8,000 & 10,206 \\
\hline \# Students & 129,326 & 198,155 & 65,183 & 100,550 & 64,143 & 97,605 \\
\hline
\end{tabular}

Note: *Significant at the 10 percent level. **Significant at the 5 percent level. ***Significant at the 1 percent level.

Source: Administrative Teacher and Student Data Set for the State of Hesse 2007/08-2011/12 (Lehrer- und Schülerdatenbank, LUSD); own calculations. 
Table 6: Robustness of Regression Results with Respect to Missing Observations for School Type Recommendation: Coefficient of Male Teacher

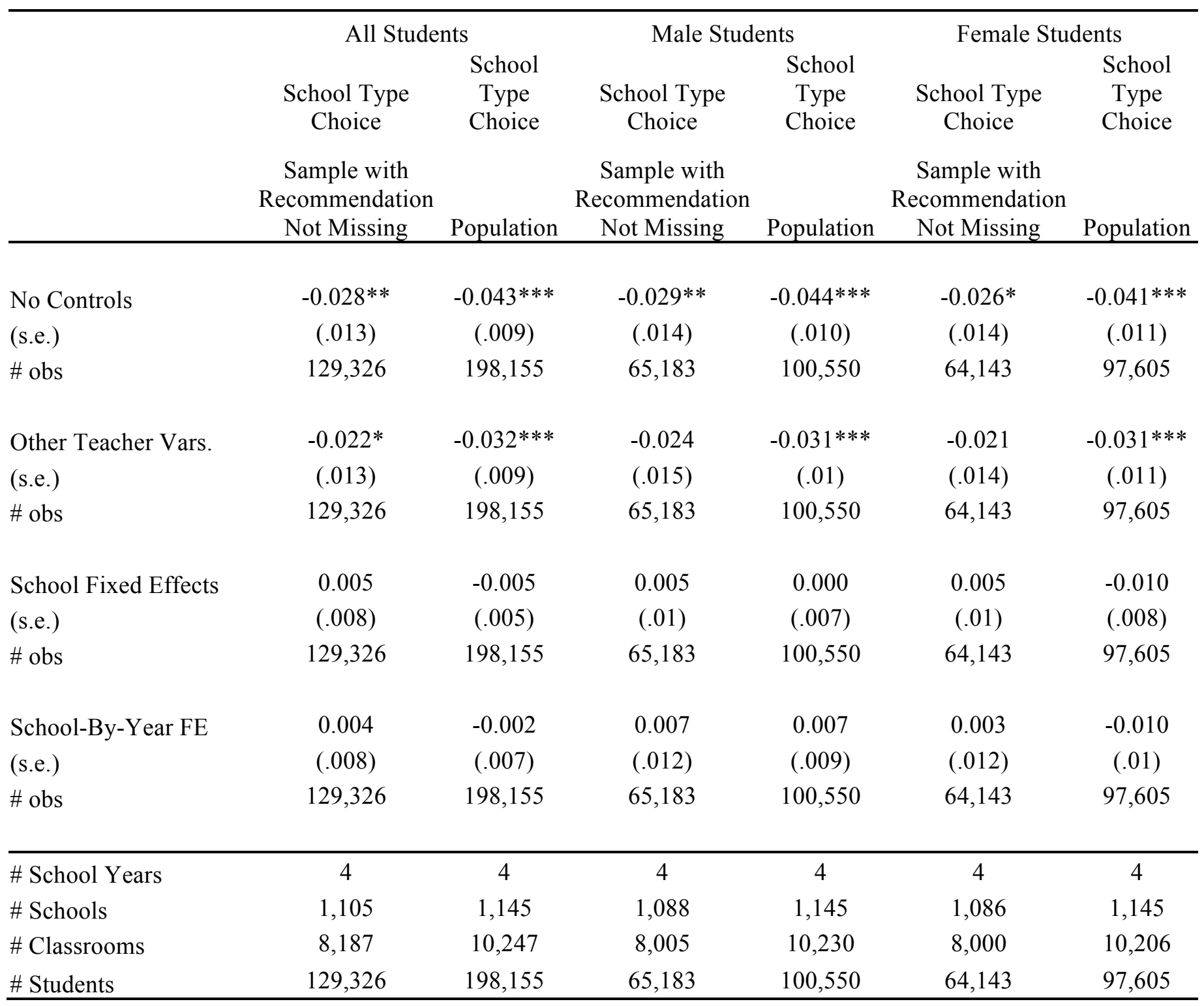

Note: *Significant at the 10 percent level. **Significant at the 5 percent level. ***Significant at the 1 percent level.

Source: Administrative Teacher and Student Data Set for the State of Hesse 2007/08-2011/12 (Lehrer- und Schülerdatenbank,

LUSD); own calculations. 
Table 7: Robustness of Regression Results Considering Only Students with Teachers of Same Gender in Core Subjects: Coefficient of Male Teacher

\begin{tabular}{|c|c|c|c|c|c|c|}
\hline & \multicolumn{2}{|c|}{ All Students } & \multicolumn{2}{|c|}{ Male Students } & \multicolumn{2}{|c|}{ Female Students } \\
\hline & $\begin{array}{c}\text { School Type } \\
\text { Recommendation }\end{array}$ & $\begin{array}{c}\text { School } \\
\text { Type } \\
\text { Choice }\end{array}$ & $\begin{array}{c}\text { School Type } \\
\text { Recommendation }\end{array}$ & $\begin{array}{c}\text { School } \\
\text { Type } \\
\text { Choice }\end{array}$ & $\begin{array}{c}\text { School Type } \\
\text { Recommendation }\end{array}$ & $\begin{array}{c}\text { School } \\
\text { Type } \\
\text { Choice }\end{array}$ \\
\hline No Controls & 0.002 & $-0.025 * *$ & 0.009 & -0.017 & -0.004 & $-0.033 * *$ \\
\hline (s.e.) & $(.014)$ & $(.011)$ & $(.015)$ & $(.012)$ & $(.016)$ & $(.013)$ \\
\hline \# obs & 109,478 & 167,673 & 55,174 & 85,020 & 54,304 & 82,653 \\
\hline $\begin{array}{l}\text { Other Teacher Vars. } \\
\text { (s.e.) }\end{array}$ & $\begin{array}{l}0.005 \\
(.014)\end{array}$ & $\begin{array}{l}-0.002 \\
(.007)\end{array}$ & $\begin{array}{l}0.012 \\
(.016)\end{array}$ & $\begin{array}{l}0.003 \\
(.009)\end{array}$ & $\begin{array}{l}0.015 \\
(.015)\end{array}$ & $\begin{array}{c}-0.011 \\
(.01)\end{array}$ \\
\hline \# obs & 109,478 & 167,673 & 55,174 & 85,020 & 54,304 & 82,653 \\
\hline School Fixed Effects & $0.021 * *$ & -0.002 & 0.019 & 0.004 & 0.019 & -0.008 \\
\hline (s.e.) & $(.01)$ & $(.007)$ & $(.012)$ & $(.009)$ & $(.014)$ & $(.011)$ \\
\hline \# obs & 109,478 & 167,673 & 55,174 & 85,020 & 54,304 & 82,653 \\
\hline School-By-Year FE & $0.024 *$ & 0.003 & 0.014 & 0.014 & $0.036^{*}$ & -0.007 \\
\hline (s.e.) & $(.013)$ & $(.009)$ & $(.015)$ & $(.012)$ & $(.019)$ & $(.014)$ \\
\hline \# obs & 109,478 & 167,673 & 55,174 & 85,020 & 54,304 & 82,653 \\
\hline \# School Years & 4 & 4 & 4 & 4 & 4 & 4 \\
\hline \# Schools & 1,076 & 1,134 & 1,059 & 1,134 & 1,060 & 1,133 \\
\hline \# Classrooms & 6,927 & 8,703 & 7,682 & 8,683 & 6,768 & 8,661 \\
\hline \# Students & 109,478 & 167,673 & 55,174 & 85,020 & 54,304 & 82,653 \\
\hline
\end{tabular}

Note: *Significant at the 10 percent level. **Significant at the 5 percent level. ***Significant at the 1 percent level.

Source: Administrative Teacher and Student Data Set for the State of Hesse 2007/08-2011/12 (Lehrer- und Schülerdatenbank, LUSD); own calculations. 
Table 8: Robustness of Regression Results Considering Teachers of All Subjects Taught: Coefficient of Male Teacher

\begin{tabular}{|c|c|c|c|c|c|c|}
\hline & \multicolumn{2}{|c|}{ All Students } & \multicolumn{2}{|c|}{ Male Students } & \multicolumn{2}{|c|}{ Female Students } \\
\hline & $\begin{array}{c}\text { School Type } \\
\text { Recommendation }\end{array}$ & $\begin{array}{c}\text { School } \\
\text { Type } \\
\text { Choice }\end{array}$ & $\begin{array}{c}\text { School Type } \\
\text { Recommendation }\end{array}$ & $\begin{array}{l}\text { School } \\
\text { Type } \\
\text { Choice } \\
\end{array}$ & $\begin{array}{c}\text { School Type } \\
\text { Recommendation }\end{array}$ & $\begin{array}{l}\text { School } \\
\text { Type } \\
\text { Choice }\end{array}$ \\
\hline No Controls & $-0.048 * *$ & $-0.074 * * *$ & $-0.039 *$ & $-0.073 * * *$ & $-0.057 * * *$ & $-0.073 * * *$ \\
\hline (s.e.) & $(.02)$ & $(.016)$ & $(.022)$ & $(.017)$ & $(.021)$ & $(.017)$ \\
\hline \# obs & 129,326 & 198,155 & 65,183 & 100,550 & 64,143 & 97,605 \\
\hline Other Teacher Vars. & $-0.036^{*}$ & -0.005 & -0.026 & 0.009 & $-0.046^{* *}$ & -0.019 \\
\hline (s.e.) & $(.02)$ & $(.008)$ & $(.022)$ & $(.011)$ & $(.021)$ & $(.011)$ \\
\hline \# obs & 129,326 & 198,155 & 65,183 & 100,550 & 64,143 & 97,605 \\
\hline School Fixed Effects & 0.014 & -0.006 & $0.027 *$ & 0.007 & 0.000 & -0.018 \\
\hline (s.e.) & $(.012)$ & $(.008)$ & $(.014)$ & $(.011)$ & $(.016)$ & $(.012)$ \\
\hline \# obs & 129,326 & 198,155 & 65,183 & 100,550 & 64,143 & 97,605 \\
\hline School-By-Year FE & 0.021 & -0.006 & $0.034 * *$ & 0.010 & 0.007 & -0.020 \\
\hline (s.e.) & $(.013)$ & $(.01)$ & $(.017)$ & $(.014)$ & $(.019)$ & $(.015)$ \\
\hline \# obs & 129,326 & 198,155 & 65,183 & 100,550 & 64,143 & 97,605 \\
\hline \# School Years & 4 & 4 & 4 & 4 & 4 & 4 \\
\hline \# Schools & 1,105 & 1,145 & 1,088 & 1,145 & 1,086 & 1,145 \\
\hline \# Classrooms & 8,187 & 10,247 & 8,005 & 10,230 & 8,000 & 10,206 \\
\hline \# Students & 129,326 & 198,155 & 65,183 & 100,550 & 64,143 & 97,605 \\
\hline
\end{tabular}

Note: *Significant at the 10 percent level. **Significant at the 5 percent level. ${ }^{* * * S i g n i f i c a n t ~ a t ~ t h e ~} 1$ percent level. Source: Administrative Teacher and Student Data Set for the State of Hesse 2007/08-2011/12 (Lehrer- und Schülerdatenbank, LUSD); own calculations. 
Table 9: Regression Results with Teacher Fixed Effects: Coefficient of Teacher of Same Gender

\begin{tabular}{lcc}
\hline & $\begin{array}{c}\text { All Students } \\
\text { School Type } \\
\text { Recommendation }\end{array}$ & $\begin{array}{c}\text { School Type } \\
\text { Choice }\end{array}$ \\
\hline Teacher Fixed Effects & 0.001 & -0.001 \\
(s.e.) & $(0.004)$ & $(0.003)$ \\
\# obs & 449,867 & 694,429 \\
Teacher-By-School FE & 0.001 & \\
(s.e.) & $(0.004)$ & -0.001 \\
\# obs & 449,867 & $(0.003)$ \\
& & 694,429 \\
\# School Years & 4 & 4 \\
\# Schools & 1,105 & 1,145 \\
\# Classrooms & 8,187 & 10,247 \\
\# Teachers & 9,933 & 11,901 \\
\# Students & 129,326 & 198,155 \\
\hline
\end{tabular}

Note: *Significant at the 10 percent level. **Significant at the 5 percent level. ***Significant at the 1 percent level.

Source: Administrative Teacher and Student Data Set for the State of Hesse 2007/08-2011/12 (Lehrer- und Schülerdatenbank, LUSD); own calculations. 
Table 10: Teacher Gender's Effect on Other Outcomes: Grade Repetition and Tracking Deferral

\begin{tabular}{|c|c|c|c|c|c|c|}
\hline & \multicolumn{2}{|c|}{ All Students } & \multicolumn{2}{|c|}{ Male Students } & \multicolumn{2}{|c|}{ Female Students } \\
\hline & $\begin{array}{c}\text { Grade } \\
\text { Repetition }\end{array}$ & $\begin{array}{l}\text { Tracking } \\
\text { Deferral }\end{array}$ & $\begin{array}{c}\text { Grade } \\
\text { Repetition }\end{array}$ & $\begin{array}{l}\text { Tracking } \\
\text { Deferral }\end{array}$ & $\begin{array}{c}\text { Grade } \\
\text { Repetition }\end{array}$ & $\begin{array}{l}\text { Tracking } \\
\text { Deferral }\end{array}$ \\
\hline No Controls & $0.003 * *$ & $0.037 * * *$ & $0.004 * *$ & $0.036^{* * *}$ & 0.002 & $0.038 * * *$ \\
\hline (s.e.) & $(.001)$ & $(.013)$ & $(.002)$ & $(.014)$ & $(.002)$ & $(.013)$ \\
\hline \# obs & 198,155 & 198,155 & 100,550 & 100,550 & 97,605 & 97,605 \\
\hline Other Teacher Vars. & $0.003 *$ & $0.029 * *$ & $0.003 *$ & $0.027^{*}$ & 0.002 & $0.031 * *$ \\
\hline (s.e.) & $(.001)$ & $(.013)$ & $(.002)$ & $(.014)$ & $(.002)$ & $(.013)$ \\
\hline \# obs & 198,155 & 198,155 & 100,550 & 100,550 & 97,605 & 97,605 \\
\hline School Fixed Effects & 0.002 & -0.004 & 0.002 & -0.008 & 0.003 & 0.002 \\
\hline (s.e.) & $(.001)$ & $(.004)$ & $(.002)$ & $(.006)$ & $(.002)$ & $(.006)$ \\
\hline \# obs & 198,155 & 198,155 & 100,550 & 100,550 & 97,605 & 97,605 \\
\hline School-By-Year FE & 0.003 & -0.004 & 0.003 & -0.007 & 0.002 & -0.001 \\
\hline (s.e.) & $(.002)$ & $(.005)$ & $(.003)$ & $(.006)$ & $(.003)$ & $(.007)$ \\
\hline \# obs & 198,155 & 198,155 & 100,550 & 100,550 & 97,605 & 97,605 \\
\hline \# School Years & 4 & 4 & 4 & 4 & 4 & 4 \\
\hline \# Schools & 1,145 & 1,145 & 1,145 & 1,145 & 1,145 & 1,145 \\
\hline \# Classrooms & 10,247 & 10,247 & 10,230 & 10,230 & 10,206 & 10,206 \\
\hline \# Students & 198,155 & 198,155 & 100,550 & 100,550 & 97,605 & 97,605 \\
\hline
\end{tabular}

Note: *Significant at the 10 percent level. **Significant at the 5 percent level. ***Significant at the 1 percent level.

Source: Administrative Teacher and Student Data Set for the State of Hesse 2007/08-2011/12 (Lehrer- und Schülerdatenbank, LUSD); own calculations. 
Table 11: Teacher Gender's Effect on Other Outcomes: Middle School Grade Retention and School Type Change

\begin{tabular}{|c|c|c|c|c|c|c|}
\hline & \multicolumn{2}{|c|}{ All Students } & \multicolumn{2}{|c|}{ Male Students } & \multicolumn{2}{|c|}{ Female Students } \\
\hline & $\begin{array}{c}\text { Grade } 3 \text { Years } \\
\text { After }\end{array}$ & $\begin{array}{c}\text { School } \\
\text { Type } \\
\text { Change }\end{array}$ & $\begin{array}{c}\text { Grade } 3 \text { Years } \\
\text { After }\end{array}$ & $\begin{array}{c}\text { School } \\
\text { Type } \\
\text { Change }\end{array}$ & $\begin{array}{c}\text { Grade } 3 \text { Years } \\
\text { After }\end{array}$ & $\begin{array}{c}\text { School } \\
\text { Type } \\
\text { Change }\end{array}$ \\
\hline No Controls & -0.005 & 0.003 & -0.004 & 0.009 & -0.005 & -0.002 \\
\hline (s.e.) & $(.004)$ & $(.007)$ & $(.005)$ & $(.007)$ & $(.004)$ & $(.008)$ \\
\hline \# obs & 99,727 & 99,727 & 50,410 & 50,410 & 49,317 & 49,317 \\
\hline Other Teacher Vars. & -0.003 & 0.001 & -0.002 & 0.008 & -0.004 & -0.005 \\
\hline (s.e.) & $(.004)$ & $(.007)$ & $(.005)$ & $(.007)$ & $(.005)$ & $(.008)$ \\
\hline \# obs & 99,727 & 99,727 & 50,410 & 50,410 & 49,317 & 49,317 \\
\hline School Fixed Effects & -0.004 & -0.005 & -0.004 & -0.001 & -0.005 & -0.008 \\
\hline (s.e.) & $(.004)$ & $(.004)$ & $(.006)$ & $(.007)$ & $(.005)$ & $(.005)$ \\
\hline \# obs & 99,727 & 99,727 & 50,410 & 50,410 & 49,317 & 49,317 \\
\hline School-By-Year FE & -0.002 & -0.002 & 0.002 & 0.001 & -0.003 & -0.006 \\
\hline (s.e.) & $(.005)$ & $(.005)$ & $(.007)$ & $(.007)$ & $(.006)$ & $(.006)$ \\
\hline \# obs & 99,727 & 99,727 & 50,410 & 50,410 & 49,317 & 49,317 \\
\hline \# School Years & 2 & 2 & 2 & 2 & 2 & 2 \\
\hline \# Schools & 1,130 & 1,130 & 1,130 & 1,130 & 1,130 & 1,130 \\
\hline \# Classrooms & 5,147 & 5,147 & 5,137 & 5,137 & 5,124 & 5,124 \\
\hline \# Students & 99,727 & 99,727 & 50,410 & 50,410 & 49,317 & 49,317 \\
\hline
\end{tabular}

Note: *Significant at the 10 percent level. **Significant at the 5 percent level. ***Significant at the 1 percent level.

Source: Administrative Teacher and Student Data Set for the State of Hesse 2007/08-2011/12 (Lehrer- und Schülerdatenbank, LUSD); own calculations. 
Table 12: Full Regression Results for School Type Recommendation as the Outcome and School Fixed Effects (cf. Table 5)

\begin{tabular}{|c|c|c|c|c|c|c|}
\hline & \multicolumn{2}{|c|}{$\begin{array}{c}\text { All Students } \\
\text { School Type } \\
\text { Recommendation }\end{array}$} & \multicolumn{2}{|c|}{$\begin{array}{c}\text { Males } \\
\text { School Type } \\
\text { Recommendation }\end{array}$} & \multicolumn{2}{|c|}{$\begin{array}{c}\text { Females } \\
\text { School Type } \\
\text { Recommendation }\end{array}$} \\
\hline & Coeff. & (s.e.) & Coeff. & (s.e.) & Coeff. & (s.e.) \\
\hline Teacher is Male & $0.01 *$ & $(.008)$ & 0.01 & $(.010)$ & 0.01 & $(.011)$ \\
\hline \multicolumn{7}{|l|}{ Teacher Age Group (40-50) } \\
\hline $20-30$ & $-0.02 * *$ & $(.009)$ & -0.02 & $(.011)$ & -0.02 & $(.012)$ \\
\hline $30-40$ & $-0.01 *$ & $(.006)$ & -0.01 & $(.008)$ & -0.01 & $(.008)$ \\
\hline $50-60$ & -0.01 & $(.006)$ & 0.00 & $(.007)$ & -0.01 & $(.008)$ \\
\hline $60-70$ & 0.00 & $(.010)$ & 0.01 & $(.013)$ & -0.02 & $(.013)$ \\
\hline \multicolumn{7}{|c|}{ Teacher Pay Level (Civil Servant A12) } \\
\hline Public Employee (BAT & 0.01 & $(.009)$ & 0.01 & $(.012)$ & 0.01 & $(.012)$ \\
\hline Civil Servant (A13) & -0.01 & $(.009)$ & 0.01 & $(.012)$ & 0.00 & $(.011)$ \\
\hline Other & $0.02 * *$ & $(.010)$ & 0.02 & $(.014)$ & 0.02 & $(.013)$ \\
\hline \multicolumn{7}{|c|}{ Teacher Qualification Level (Elementary) } \\
\hline Below Elementary & 0.00 & $(.010)$ & 0.01 & $(.014)$ & 0.00 & $(.013)$ \\
\hline Above Elementary & 0.00 & $(.009)$ & 0.00 & $(.011)$ & -0.01 & $(.012)$ \\
\hline Other & -0.02 & $(.013)$ & $-0.03 * *$ & $(.017)$ & $-0.01 *$ & $(.019)$ \\
\hline Teacher Not German & 0.00 & $(.038)$ & 0.00 & $(.040)$ & -0.01 & $(.053)$ \\
\hline \multicolumn{7}{|c|}{ Teacher Working Hours (26-50) } \\
\hline $0-20$ & 0.00 & $(.007)$ & 0.00 & $(.009)$ & 0.01 & $(.010)$ \\
\hline $20-26$ & -0.01 & $(.005)$ & 0.01 & $(.007)$ & 0.01 & $(.007)$ \\
\hline Share Female in Classroom & 0.02 & $(.016)$ & $0.06 * * *$ & $(.021)$ & -0.01 & $(.022)$ \\
\hline Share Non-Europ. in Classr. & 0.01 & $(.030)$ & 0.03 & $(.039)$ & -0.01 & $(.037)$ \\
\hline Enrollment/10 & -0.01 & $(.007)$ & -0.01 & $(.009)$ & 0.00 & $(.009)$ \\
\hline Enrollment Squared/1000 & 0.01 & $(.005)$ & 0.01 & $(.006)$ & 0.01 & $(.006)$ \\
\hline Student Male & $-0.02 * * *$ & $(.003)$ & - & - & - & - \\
\hline Student Age & $-0.22 * * *$ & $(.003)$ & $-0.23 * * *$ & $(.004)$ & $-0.21 *$ & $(.004)$ \\
\hline \multicolumn{7}{|l|}{ Student Citizenship } \\
\hline Turkish & $-0.25 * * *$ & $(.007)$ & $-0.23 * * *$ & $(.009)$ & $-0.26 * * *$ & $(.010)$ \\
\hline Europ., North Am., & $-0.16 * * *$ & $(.007)$ & $-0.16 * * *$ & $(.010)$ & $-0.15 * * *$ & $(.010)$ \\
\hline Other & $-0.18 * * *$ & $(.010)$ & $-0.17 * * *$ & $(.013)$ & $-0.19 * * *$ & $(.013)$ \\
\hline \multicolumn{7}{|l|}{ School Year (2008/09) } \\
\hline $2007 / 08$ & $-0.01 *$ & $(.005)$ & -0.01 & $(.006)$ & -0.01 & $(.007)$ \\
\hline $2009 / 10$ & 0.01 & $(.005)$ & 0.00 & $(.006)$ & 0.01 & $(.007)$ \\
\hline $2010 / 11$ & 0.01 & $(.006)$ & 0.01 & $(.008)$ & 0.00 & $(.007)$ \\
\hline Constant & $2.72 * * *$ & $(.039)$ & $2.75 * * *$ & $(.050)$ & $2.66 * * *$ & $(.052)$ \\
\hline $\mathrm{R}^{2}$ & 0.21 & & 0.21 & & 0.19 & \\
\hline \# School Years & 4 & & 4 & & 4 & \\
\hline \# Schools & 1,105 & & 1,088 & & 1,086 & \\
\hline \# Classrooms & 8,187 & & 8,005 & & 8,000 & \\
\hline \# Students & 129,326 & & 65,183 & & 64,143 & \\
\hline
\end{tabular}

Note: *Significant at the 10 percent level. **Significant at the 5 percent level. ***Significant at the 1 percent level. Source: Administrative Teacher and Student Data Set for the State of Hesse 2007/08-2011/12 (Lehrer- und Schülerdatenbank, LUSD); own calculations. 
Table 13: Full Regression Results for School Type Choice as the Outcome and School Fixed Effects (cf. Table 5)

\begin{tabular}{|c|c|c|c|c|c|c|}
\hline & \multicolumn{2}{|c|}{$\begin{array}{c}\text { All students } \\
\text { School Type Choice }\end{array}$} & \multicolumn{2}{|c|}{$\begin{array}{c}\text { Males } \\
\text { School Type Choice }\end{array}$} & \multicolumn{2}{|c|}{$\begin{array}{c}\text { Females } \\
\text { School Type Choice }\end{array}$} \\
\hline & Coeff. & (s.e.) & Coeff. & (s.e.) & Coeff. & (s.e.) \\
\hline Teacher is Male & 0.00 & $(.005)$ & 0.000 & $(.007)$ & -0.01 & $(.008)$ \\
\hline \multicolumn{7}{|l|}{ Teacher Age Group (40-50) } \\
\hline $20-30$ & 0.00 & $(.006)$ & 0.013 & $(.009)$ & -0.01 & $(.009)$ \\
\hline $30-40$ & 0.00 & $(.005)$ & 0.005 & $(.006)$ & -0.01 & $(.007)$ \\
\hline $50-60$ & 0.00 & $(.004)$ & 0.001 & $(.006)$ & -0.01 & $(.006)$ \\
\hline $60-70$ & 0.00 & $(.007)$ & 0.013 & $(.009)$ & -0.01 & $(.010)$ \\
\hline \multicolumn{7}{|c|}{ Teacher Pay Level (Civil Servant A12) } \\
\hline $\begin{array}{l}\text { Public Employee (BAT } \\
\text { III) }\end{array}$ & 0.00 & $(.007)$ & 0.005 & $(.009)$ & 0.00 & $(.009)$ \\
\hline Civil Servant (A13) & 0.00 & $(.006)$ & -0.009 & $(.009)$ & 0.00 & $(.009)$ \\
\hline Other & 0.01 & $(.008)$ & 0.007 & $(.010)$ & 0.02 & $(.010)$ \\
\hline \multicolumn{7}{|c|}{ Teacher Qualification Level (Elementary) } \\
\hline Below Elementary & -0.01 & $(.007)$ & -0.003 & $(.010)$ & -0.01 & $(.010)$ \\
\hline Above Elementary & 0.00 & $(.006)$ & 0.004 & $(.008)$ & 0.00 & $(.008)$ \\
\hline Other & 0.00 & $(.009)$ & -0.011 & $(.013)$ & 0.00 & $(.014)$ \\
\hline Teacher Not German & -0.04 & $(.026)$ & -0.017 & $(.035)$ & $-0.07 *$ & $(.038)$ \\
\hline \multicolumn{7}{|c|}{ Teacher Working Hours (26-50) } \\
\hline $0-20$ & 0.00 & $(.005)$ & -0.006 & $(.007)$ & 0.01 & $(.007)$ \\
\hline $20-26$ & 0.00 & $(.004)$ & 0.001 & $(.005)$ & 0.01 & $(.005)$ \\
\hline Share Female in Classroom & 0.02 & $(.012)$ & $0.06 * * *$ & $(.017)$ & -0.02 & $(.017)$ \\
\hline Share Non-Europ. in Classr. & -0.01 & $(.021)$ & 0.01 & $(.029)$ & -0.03 & $(.028)$ \\
\hline Enrollment/10 & -0.01 & $(.005)$ & $-0.01 *$ & $(.007)$ & 0.00 & $(.007)$ \\
\hline Enrollment Squared/1000 & 0.00 & $(.004)$ & 0.01 & $(.005)$ & 0.00 & $(.005)$ \\
\hline Student Male & $-0.01 * * *$ & $(.002)$ & - & - & - & - \\
\hline Student Age & $-0.23 * * *$ & $(.003)$ & $-0.23 * * *$ & $(.003)$ & $-0.22 * * *$ & $(.003)$ \\
\hline \multicolumn{7}{|l|}{$\begin{array}{l}\text { Student Citizenship } \\
\text { (German) }\end{array}$} \\
\hline Turkish & $-0.15 * * *$ & $(.006)$ & $-0.14 * * *$ & $(.007)$ & $-0.15 * * *$ & $(.008)$ \\
\hline $\begin{array}{l}\text { Europ., North Am., } \\
\text { Aus./NZ }\end{array}$ & $-0.11 * * *$ & $(.006)$ & $-0.11 * * *$ & $(.008)$ & $-0.10 * * *$ & $(.008)$ \\
\hline Other & $-0.09 * * *$ & $(.008)$ & $-0.09 * * *$ & $(.010)$ & $-0.10 * * *$ & $(.011)$ \\
\hline \multicolumn{7}{|l|}{ School Year (2008/09) } \\
\hline $2007 / 08$ & $-0.01 * * *$ & $(.003)$ & $-0.01 * * *$ & $(.004)$ & 0.00 & $(.005)$ \\
\hline $2009 / 10$ & 0.00 & $(.003)$ & -0.00 & $(.005)$ & 0.00 & $(.005)$ \\
\hline 2010/11 & 0.00 & $(.004)$ & 0.00 & $(.005)$ & 0.00 & $(.005)$ \\
\hline Constant & $2.71 * * *$ & $(.034)$ & $2.75 * * *$ & $(.042)$ & $2.66 * * *$ & $(.042)$ \\
\hline $\mathrm{R}^{2}$ & 0.16 & & 0.17 & & 0.16 & \\
\hline \# School Years & 4 & & 4 & & 4 & \\
\hline \# Schools & 1,145 & & 1,145 & & 1,145 & \\
\hline \# Classrooms & 10,247 & & 10,230 & & 10,206 & \\
\hline \# Students & 198,155 & & 100,550 & & 97,605 & \\
\hline
\end{tabular}

Note: *Significant at the 10 percent level. **Significant at the 5 percent level. ***Significant at the 1 percent level.

Source: Administrative Teacher and Student Data Set for the State of Hesse 2007/08-2011/12 (Lehrer- und Schülerdatenbank, LUSD); own calculations. 
Figure 1: School Choice After Final Year (Grade 4) of Elementary School

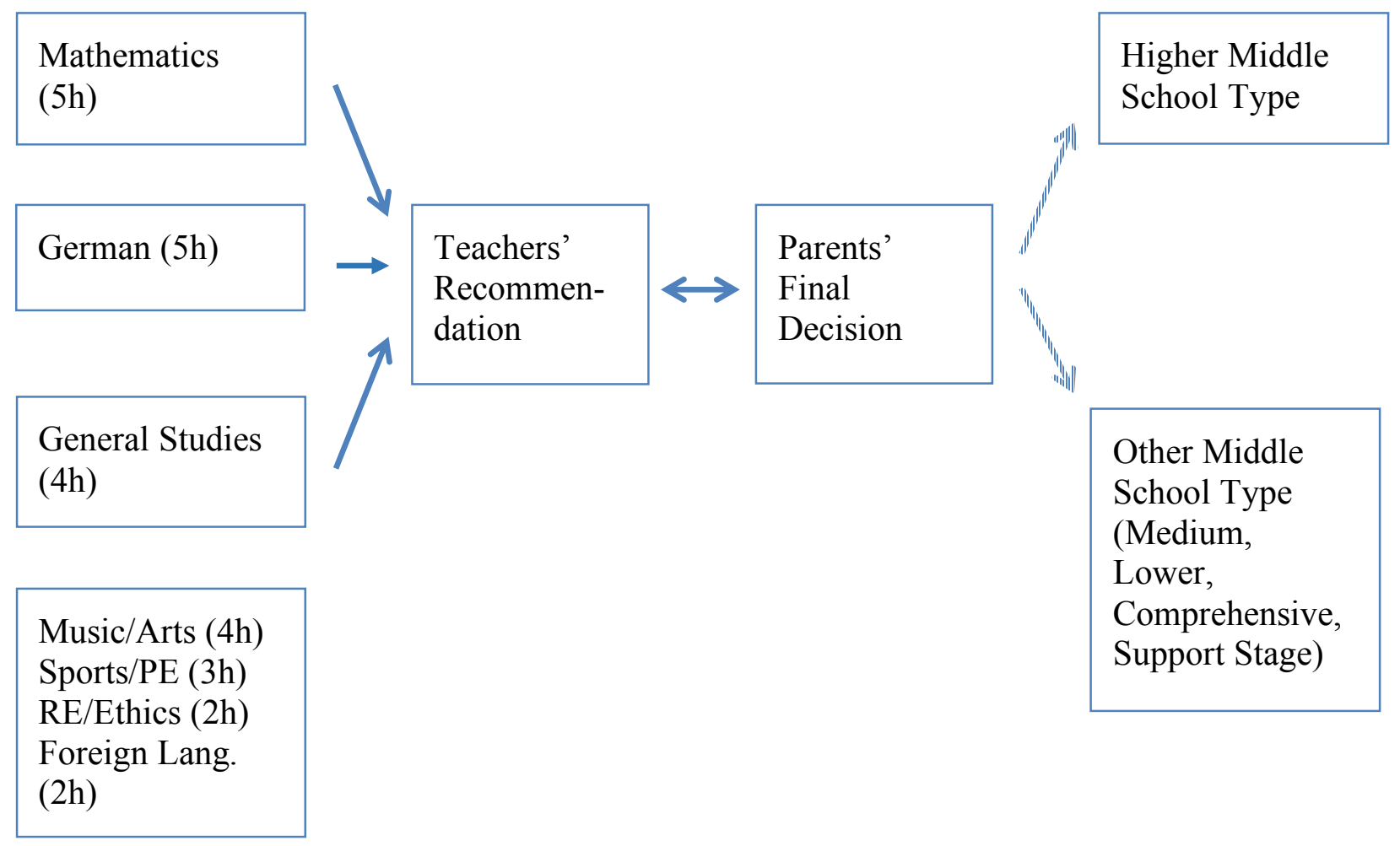

Source: Ministry of Culture and Education (Kultusministerium) of the state of Hesse; own illustration. 


\section{Appendix}

\section{Table A1: Sample Sizes}

\begin{tabular}{lccccc}
\hline School Year & $\begin{array}{c}\text { \# Students in } \\
\text { 4th Grade } \\
\text { Elementary } \\
\text { School }\end{array}$ & $\begin{array}{c}\text { \# Students } \\
\text { Present in } \\
\text { Hesse in the } \\
\text { Following } \\
\text { School Year }\end{array}$ & $\begin{array}{c}\text { \# Students } \\
\text { After Merging } \\
\text { Student Data } \\
\text { with School } \\
\text { Data }\end{array}$ & $\begin{array}{c}\text { \# Students } \\
\text { After Merging } \\
\text { with Course } \\
\text { and Teacher } \\
\text { Data }\end{array}$ & $\begin{array}{c}\text { \# Students by } \\
\text { Courses in } \\
\text { Math, German, } \\
\text { and General } \\
\text { Studies }\end{array}$ \\
\hline $2007 / 08-2008 / 09$ & 58,473 & 54,523 & 53,019 & 50,070 & 175,419 \\
$2008 / 09-2009 / 10$ & 57,562 & 53,916 & 52,495 & 49,657 & 177,374 \\
$2009 / 10-2010 / 11$ & 55,976 & 53,921 & 52,409 & 50,341 & 160,380 \\
$2010 / 11-2011 / 12$ & 54,136 & 51,170 & 49,520 & 48,087 & 168,788 \\
\hline Total & 226,147 & 213,530 & 207,443 & 198,155 & 694,429 \\
\hline
\end{tabular}

Source: Administrative Teacher and Student Data Set for the State of Hesse 2007/08-2011/12 (Lehrer- und Schülerdatenbank, LUSD); own calculations. 
Table A2: $F$-Statistics and $P$-Values on Joint Effects of the Male Teacher Variables in School Grades 2, 3, and 4

\begin{tabular}{|c|c|c|c|c|c|c|c|c|}
\hline & \multicolumn{4}{|c|}{ Teacher Gender in Grades 3 and 4} & \multicolumn{4}{|c|}{ Teacher Gender in Grades 2, 3 and 4} \\
\hline & \multicolumn{2}{|c|}{ Male Students } & \multicolumn{2}{|c|}{ Female Students } & \multicolumn{2}{|c|}{ Male Students } & \multicolumn{2}{|c|}{ Female Students } \\
\hline & $\begin{array}{l}\text { Track } \\
\text { Re- } \\
\text { commen- } \\
\text { dation }\end{array}$ & $\begin{array}{l}\text { Track } \\
\text { Choice }\end{array}$ & $\begin{array}{l}\text { Track } \\
\text { Re- } \\
\text { commen- } \\
\text { dation }\end{array}$ & $\begin{array}{c}\text { Track } \\
\text { Choice }\end{array}$ & $\begin{array}{c}\text { Track } \\
\text { Re- } \\
\text { commen- } \\
\text { dation } \\
\end{array}$ & $\begin{array}{c}\text { Track } \\
\text { Choice }\end{array}$ & $\begin{array}{l}\text { Track } \\
\text { Re- } \\
\text { commen- } \\
\text { dation } \\
\end{array}$ & $\begin{array}{l}\text { Track } \\
\text { Choice }\end{array}$ \\
\hline No Controls & 1.75 & $8.65^{* *}$ & 2.13 & $7.51 * * *$ & 2.06 & $5.05 * * *$ & 1.13 & $4.61 * * *$ \\
\hline ( $p$-value) & $(.17)$ & $(.00)$ & $(.12)$ & $(.00)$ & $(.10)$ & $(.00)$ & $(.34)$ & $(.00)$ \\
\hline \# obs & 44,659 & 70,082 & 44,032 & 68,337 & 27,416 & 43,294 & 26,845 & 42,006 \\
\hline Other Teacher Vars & 0.61 & $3.29 * *$ & 1.77 & $4.29 * *$ & 0.76 & $2.34 *$ & 1.40 & $4.66^{* * *}$ \\
\hline ( $p$-value) & $(.54)$ & $(.04)$ & $(.17)$ & $(.01)$ & $(.51)$ & $(.07)$ & $(.24)$ & $(.00)$ \\
\hline \# obs & 44,659 & 70,082 & 44,032 & 68,337 & 27,416 & 43,294 & 26,845 & 42,006 \\
\hline School Fixed Effects & 0.18 & $2.38^{*}$ & 0.32 & 0.86 & 0.12 & $2.54^{*}$ & 0.44 & 0.94 \\
\hline ( $p$-value) & $(.84)$ & $(.09)$ & $(.73)$ & $(.42)$ & $(.95)$ & $(.06)$ & $(.72)$ & $(.42)$ \\
\hline \# obs & 44,659 & 70,082 & 44,032 & 68,337 & 27,416 & 43,294 & 26,845 & 42,006 \\
\hline School By Year FE & 0.69 & $3.48 * *$ & 0.46 & 0.44 & 0.07 & 1.39 & 0.34 & 1.58 \\
\hline ( $p$-value) & $(.50)$ & $(.03)$ & $(.63)$ & (.64) & $(.98)$ & $(.24)$ & $(.80)$ & $(.19)$ \\
\hline \# obs & 44,659 & 70,082 & 44,032 & 68,337 & 27,416 & 43,294 & 26,845 & 42,006 \\
\hline Corr. (TG2, TG4) & - & - & - & - & 0.6087 & 0.6137 & 0.6069 & 0.6079 \\
\hline Corr. (TG3, TG4) & 0.7762 & 0.7802 & 0.7793 & 0.7816 & 0.7743 & 0.7823 & 0.7799 & 0.7844 \\
\hline \# School Years & 3 & 3 & 3 & 3 & 2 & 2 & 2 & 2 \\
\hline \# Schools & 1,052 & 1,196 & 1,030 & 1,165 & 939 & 1,130 & 928 & 1,124 \\
\hline \# Classrooms & 5,639 & 7,432 & 5,635 & 7,411 & 3,613 & 4,822 & 3,616 & 4,825 \\
\hline \# Teachers & 6,802 & 9,350 & 6,687 & 9,117 & 4,299 & 5,936 & 4,250 & 5,822 \\
\hline \# Students & 44,659 & 70,082 & 44,032 & 68,337 & 27,416 & 43,294 & 26,845 & 42,006 \\
\hline
\end{tabular}

Note: *Significant at the 10 percent level. ${ }^{*}$ Significant at the 5 percent level. ***Significant at the 1 percent level. Corr. (TG2, TG4) is the correlation of the male teacher variables relating to grades 2 and 4 . Corr. (TG3, TG4) is the correlation of the male teacher variables relating to grades 3 and 4 .

Source: Administrative Teacher and Student Data Set for the State of Hesse 2007/08-2011/12 (Lehrer- und Schülerdatenbank, LUSD); own calculations. 
Figure A1: Power Curves Corresponding to Standard Errors Observed in Table 5

A. Power Curve Corresponding to a Standard Error of 0.014

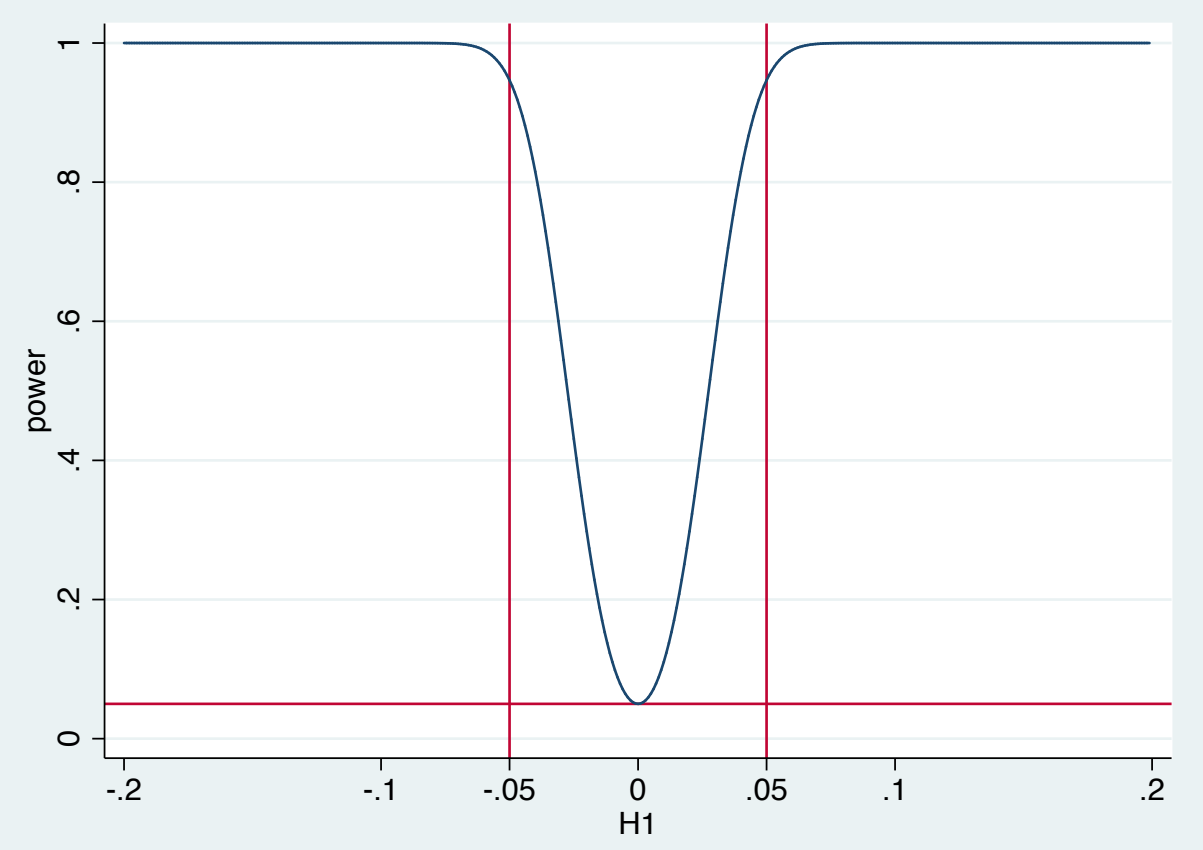

B. Power Curve Corresponding to a Standard Error of 0.008

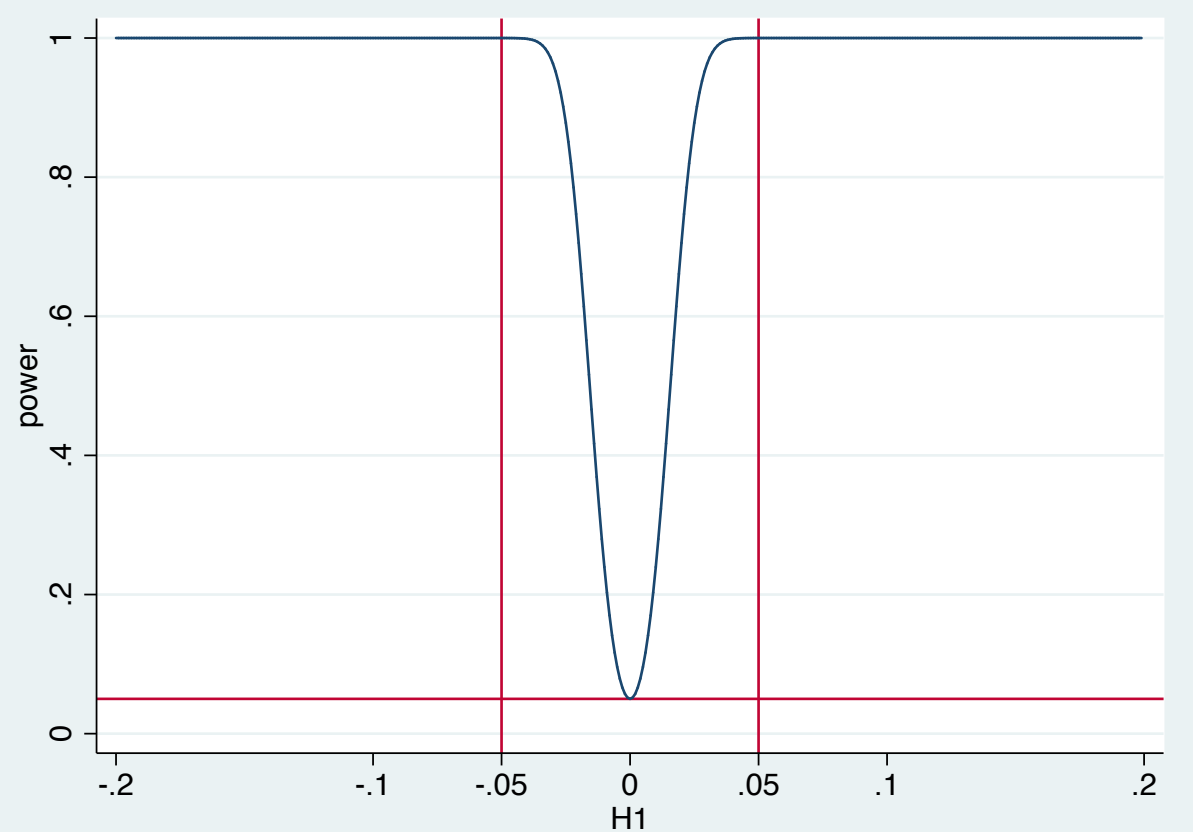

Source: Administrative Teacher and Student Data Set for the State of Hesse 2007/08-2011/12 (Lehrer- und Schülerdatenbank, LUSD); own calculations. 